\title{
Towards resilience through systems-based plant breeding. A review
}

\author{
Edith T. Lammerts van Bueren ${ }^{1,2} \cdot$ Paul C. Struik $^{3} \cdot$ Nick van Eekeren $^{1} \cdot$ Edwin Nuijten $^{1}$
}

Accepted: 13 July 2018 / Published online: 22 August 2018

(C) The Author(s) 2018

\begin{abstract}
How the growing world population can feed itself is a crucial, multi-dimensional problem that goes beyond sustainable development. Crop production will be affected by many changes in its climatic, agronomic, economic, and societal contexts. Therefore, breeders are challenged to produce cultivars that strengthen both ecological and societal resilience by striving for six international sustainability targets: food security, safety and quality; food and seed sovereignty; social justice; agrobiodiversity; ecosystem services; and climate robustness. Against this background, we review the state of the art in plant breeding by distinguishing four paradigmatic orientations that currently co-exist: community-based breeding, ecosystem-based breeding, trait-based breeding, and corporate-based breeding, analyzing differences among these orientations. Our main findings are: (1) all four orientations have significant value but none alone will achieve all six sustainability targets; (2) therefore, an overarching approach is needed: "systems-based breeding," an orientation with the potential to synergize the strengths of the ways of thinking in the current paradigmatic orientations; (3) achieving that requires specific knowledge development and integration, a multitude of suitable breeding strategies and tools, and entrepreneurship, but also a change in attitude based on corporate responsibility, circular economy and true-cost accounting, and fair and green policies. We conclude that systems-based breeding can create strong interactions between all system components. While seeds are part of the common good and the basis of agrobiodiversity, a diversity in breeding approaches, based on different entrepreneurial approaches, can also be considered part of the required agrobiodiversity. To enable systems-based breeding to play a major role in creating sustainable agriculture, a shared sense of urgency is needed to realize the required changes in breeding approaches, institutions, regulations and protocols. Based on this concept of systems-based breeding, there are opportunities for breeders to play an active role in the development of an ecologically and societally resilient, sustainable agriculture.
\end{abstract}

Keywords Agrobiodiversity $\cdot$ Breeding strategies $\cdot$ Common good $\cdot$ Ecological resilience $\cdot$ Entrepreneurial models $\cdot$ Resource use efficiency $\cdot$ Seed systems $\cdot$ Social justice $\cdot$ Societal resilience $\cdot$ Sustainability

Edith T. Lammerts van Bueren edith.lammertsvanbueren@wur.nl

$1 \quad$ Louis Bolk Institute, Kosterijland 3-5, 3981 AJ Bunnik, The Netherlands

2 Department of Plant Sciences, Wageningen UR Plant Breeding, Wageningen University and Research, P.O. Box 386, 6700 AJ Wageningen, The Netherlands

3 Department of Plant Sciences, Centre for Crop Systems Analysis, Wageningen University and Research, P.O. Box 430, 6700 AK Wageningen, The Netherlands

\section{Contents}

1. Introduction

2. The roles and positioning of plant breeding and seed systems in food systems

3. Diverse orientations in plant breeding and the seed sector

3.1. Community-based breeding

3.2. Ecosystem-based breeding

3.3. Trait-based breeding

3.4. Corporate-based breeding

3.5. The need to combine potentials of the four paradigmatic orientations

4. Defining a systems-based breeding orientation

4.1. Required change in attitude

4.2. From attitude to action

4.3. From action to achievement

5. Discussion and conclusions 
5.1. Diversity of breeding initiatives and variety registration protocols

5.2. Seeds as common good

5.3. New entrepreneurial models

5.4. Shared sense of urgency

5.5. Perspective

References

\section{Introduction}

Since the 1950s, agricultural policies were very conducive to increasing yield per hectare and per unit of labor. Consequently, plant breeding was strongly oriented towards creating cultivars that were highly productive and suitable for machine-harvesting in large-scale, high-external-input farming systems (Fraser et al. 2016; Bradshaw 2017). However, during the last few decades, awareness of the negative side-effects of these policies, for example on the environment, the sustainability of food production systems, the agrobiodiversity and ecosystem services of agroecosystems, has been increasing. It became apparent that a societal debate is required to assess and evaluate multi-dimensional trade-offs in food production, with respect for and accepting differences in norms and values (Struik et al. 2014; Struik and Kuyper 2017). We need to rethink and reorganize our food systems, i.e., the way we produce, harvest, store, transport, process, market, and consume (or dispose of) our food.

In addition to the need to restore the sustainability of the production systems, food security, food safety, food quality, and food sovereignty for a rapidly growing and increasingly demanding world population are urgent issues requiring continuous crop improvement, yield gains, and reductions of losses of produce during harvesting, storage, and processing (FAO 2016; FAO et al. 2017). Most scientists assume that realizing these demands requires doubling global food production by 2050 (for a debate on this need, see Tomlinson 2013), based on sustainable intensification. FAO (2001) defined food security as "a situation that exists when all people, at all times, have physical, social and economic access to sufficient, safe and nutritious food that meets their dietary needs and food preferences for an active and healthy life." Food safety is part of that food security concept: it is the absence of harmful or health-threatening components in the food. Positive aspects related to nutritious and healthy food need to be addressed more explicitly (Dwivedi et al. 2017). In this paper, it is covered in the phrase food quality. Food sovereignty is a much wider concept than food security: it is the right of local communities to define and control their own food systems (see, e.g., Wittman 2011). Food sovereignty encompasses the equity and ecological foundations for the achievement of food security, including farmer autonomy and sustainable use of natural resources, actively involving urban dwellers (especially women) in the food system, and not merely as consumers, and free access to and control over seed (Bezner Kerr 2010; Snapp et al. 2010; Wittman 2011; Alkon 2013; Barthel et al. 2013; Montenegro de Wit 2016). Food sovereignty includes self-organized systems of rules and diverse packages of practices and technologies from creating varieties, producing seed, growing crops, processing the harvest, all the way to marketing the produce (Barthel et al. 2013). The diversity of crops and food sources is an issue in itself as it affects the stability of the global food system. There is concern that crop diversity is in decline (Khoury et al. 2014). Here, we stress that food sovereignty is only possible when also seed sovereignty is guaranteed, i.e., when agrobiodiversity and the resulting seed (system) are considered as commons and public good and managed based on the rules that apply for common-pool resources (Ostrom 2008).

Biodiversity and ecosystem services are key factors that regulate and support the environment within agro-ecosystems, sustain future food production, and contribute to natural pest control, pollination, nutrient (re)cycling, soil conservation (structure and fertility), water provision (quality and quantity), carbon sequestration, etc. (Power 2010; Harrison et al. 2014; Huang et al. 2015), i.e., they contribute to sustainable intensification. FAO (2011) defined sustainable intensification as "producing more from the same area of land while conserving resources, reducing negative impacts on the environment and enhancing natural capital and the flow of ecosystem services," although the entire concept of sustainable intensification has been disputed (Struik et al. 2014; Struik et al. 2017). It is only possible with substantial and long-term efforts, not only from agronomists and breeders, but also from other players in the food system, such as processors, retailers, and consumers. At the same time, agricultural production must also be made climate-robust, i.e., all players in the food system, including plant breeders, must find ways to mitigate the negative effects of climate change, with its increasingly unpredictable and extreme weather patterns, on the food system. Obviously, increasing yields should not go to the detriment of nutritional quality, taste and other food qualities.

With such enormous tasks ahead, one would expect that farmers, breeders, scientists, and other involved chain actors would get all the support from national and international governments and institutions required to achieve their goals. Unfortunately, this is not the case: agriculture, breeding, and agronomy have become contested despite their great successes (Khush 2001) and they are currently confronted with multifaceted challenges set by national and supra-national policy targets, environmentalists, and pressure groups (Kiers et al. 2008; Brussaard et al. 2010; Power 2010; Lauer et al. 2012; Sumberg et al. 2013). These challenges cannot be met by technical solutions alone, but require solutions that take socio-economic, ethical, and judicial aspects into account, such as social justice (for example equal access to knowledge and technologies) (Tilman et al. 2002; Kiers et al. 2008; Brussaard et al. 2010; Koohafkan et al. 2012; Kuyper and 
Struik 2014; Struik and Kuyper 2014; Struik et al. 2014; United Nations 2015; FAO 2016; FAO et al. 2017; Struik and Kuyper 2017). Therefore, an integrated approach is needed based on comparative and quantitative analyses of tradeoffs (with multiple temporal and spatial dimensions) to strengthen ecological resilience in combination with societal debates on norms and values, negotiations between stakeholders, and subsequent political choices on how to produce (Hisschemöller and Hoppe 1995; Kiers et al. 2008; Struik and Kuyper 2017) in order to strengthen societal resilience.

Starting in the 1980s, various scientists have substantiated that, in addition to breeders, farmers and other chain actors have a role to play in improving ecological resilience through selecting for higher yielding varieties (Sperling et al. 1993; Ceccarelli et al. 2001) and maintaining high levels of crop diversity (Teshome et al. 1997; Zimmerer 1998). From the 1990s onwards, initiatives were developed to improve societal resilience through so-called participatory plant breeding (Sperling et al. 2001), in some cases with a particular focus on the empowerment of women (Galiè et al. 2017). However, valuable lessons learned from these studies have not reached the mainstream debate on the future of agriculture.

In short, the necessary sustainable intensification of agriculture aiming at both ecological and societal resilience requires a major effort from politics, society, farmers, other value chain actors, and science. In this context, practitioners and scientists involved in plant breeding and seed systems have a major role to play.

Figures 1 and 2 provide some examples of ecological and societal resilience.

In this paper, we analyze and discuss the role of plant breeding and seed systems in designing the future directions towards meeting the six international policy targets on agrobiodiversity; climate robustness; ecosystem services; food security, safety and quality; food and seed sovereignty; and social justice. In order to evaluate (i) how plant breeding has shaped the development of agricultural production, including both positive and unintended negative side-effects, (ii) how it can contribute to mitigating these negative side-effects, (iii) how it can become involved in the debate and negotiations on how to re-organize our food systems, and (iv) how it can contribute to meeting current and future challenges, we will first describe the position of the breeding and seed systems within their economic, institutional and cultural context. We will then analyze four existing orientations of plant breeding, and define their main characteristics, strengths and weaknesses. We will use that analysis to propose a new concept, which we coin "systems-based breeding" and which will help plant breeders to navigate when they are designing new programs to support the creation of sustainable food systems. Finally, we will also discuss key trends that need to be supported on the route towards such systems-based breeding.

\section{The roles and positioning of plant breeding} and seed systems in food systems

Breeding and seed systems have specific roles and are influenced by a complexity of socio-economic, historical, and socio-political factors. An illustration of these roles and influences is necessary to understand the playing field in which the breeding and seed systems are positioned and in which choices can be made that will direct future opportunities. Figure 3 illustrates the roles, positioning, and interwovenness of formal plant breeding and seed systems (i.e., described by official law and regulations, leading to certified seed of verified varieties) and informal plant breeding and seed systems (farmer-led, including farmers' variety selection, seed production, and seed exchange activities), in food systems with various types of societal factors. These factors include: (i) the markets and their value chains, (ii) policy and governance in relation to genetic resources, variety testing and registration, intellectual property rights, etc., (iii) science and technology supporting the development of breeding products and tools, and (iv) societal and cultural norms and values defining acceptability of approaches and products.

During the past century, the nature of breeding in industrialized countries has changed substantially from farm-based seed production and selection activities leading to locally adapted landraces via commercial breeding supported by publicly funded breeding of genitors (e.g., with new resistance genes from wild relatives), more and more towards a scienceand corporate-based activity concentrated in highly specialized and internationally operating multinationals. Parallel to these changes in breeding systems, the seed systems in industrialized countries developed from open, informal seed systems based on farm-saved seed and community seed networks based on sharing and exchange, supporting seed sovereignty, towards formal, more closed seed systems with strong oversight and certification systems to guarantee genetic, physical, physiological, and phytosanitary quality of seed. In these formal seed systems, the seed multiplication became a corporate specialization, where farmers faced dispossession and lost sovereignty over seed; farmers lost the opportunity to multiply their own seed on-farm, either for biological reasons (through the provision of irreproducible F1 hybrid seeds) or for legal reasons (based on restrictive seed laws on farm-saved seeds or by patent rules) (Kloppenburg 2010). These developments denied the positive role of farmers or community seed networks in maintaining agricultural diversity (Coomes et al. 2015 and references therein).

Simultaneously, public plant breeding and variety testing schemes have been strongly down-sized, while private companies concentrate more and more on a limited assortment of cash crops in an economically highly competitive market. Currently, mainstream large plant breeding companies in industrialized countries have their own Research and Development 


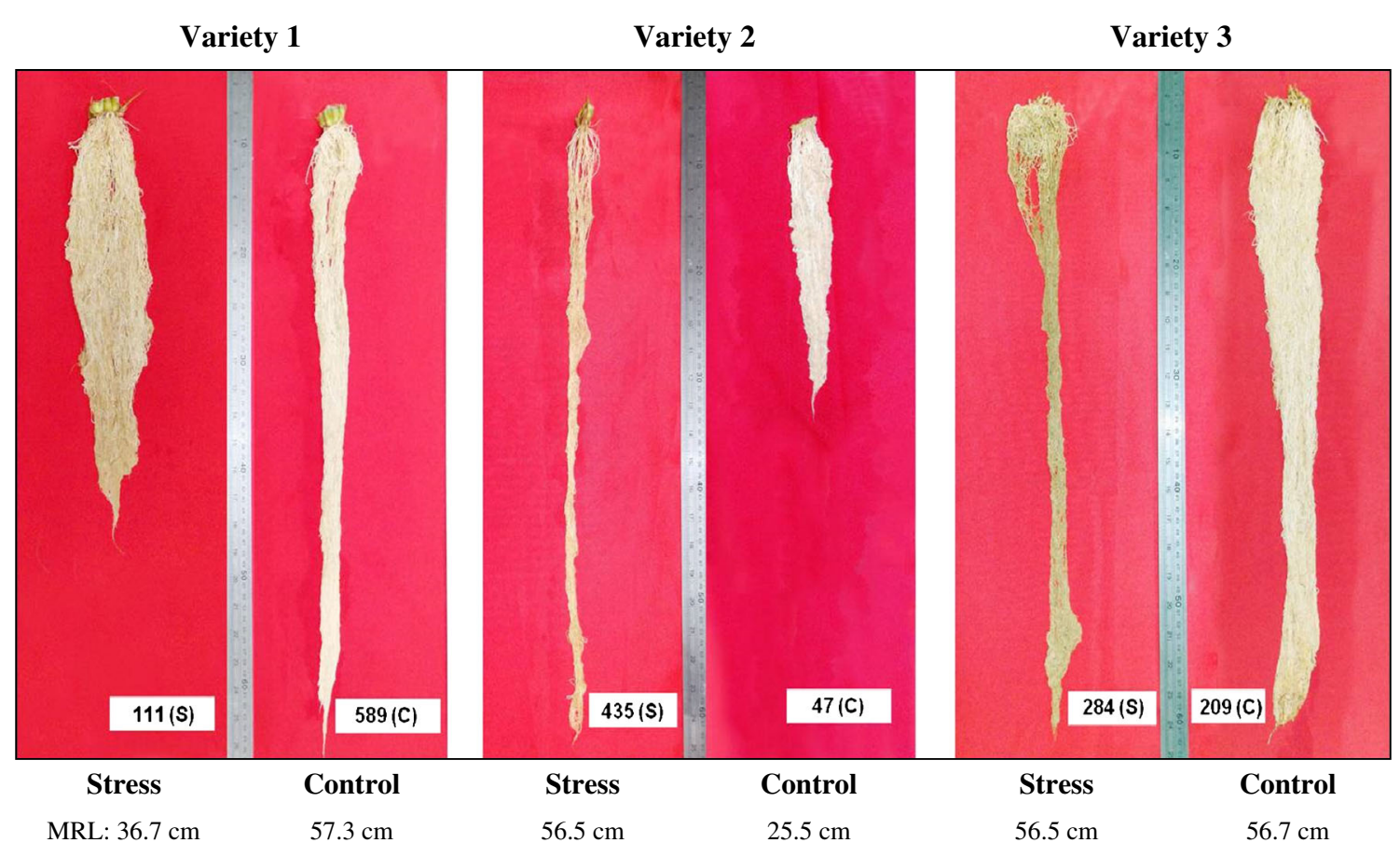

Fig. 1 Ecological resilience in rice. The figure shows different types of phenotypic plasticity in response to water-deficit stress during the vegetative stage. Variety 1 shows a root system with a short root length under water deficit compared to the control, Variety 2 shows a longer root system under water deficit compared to the control, whereas Variety 3

departments to increase speed and efficiency of the breeding process including marker-assisted selection based on the opportunities offered by genomics (and other "omics") in combination with advanced processing techniques of big data and modeling approaches (Yin and Struik 2016). These developments require large investments in technologies and human

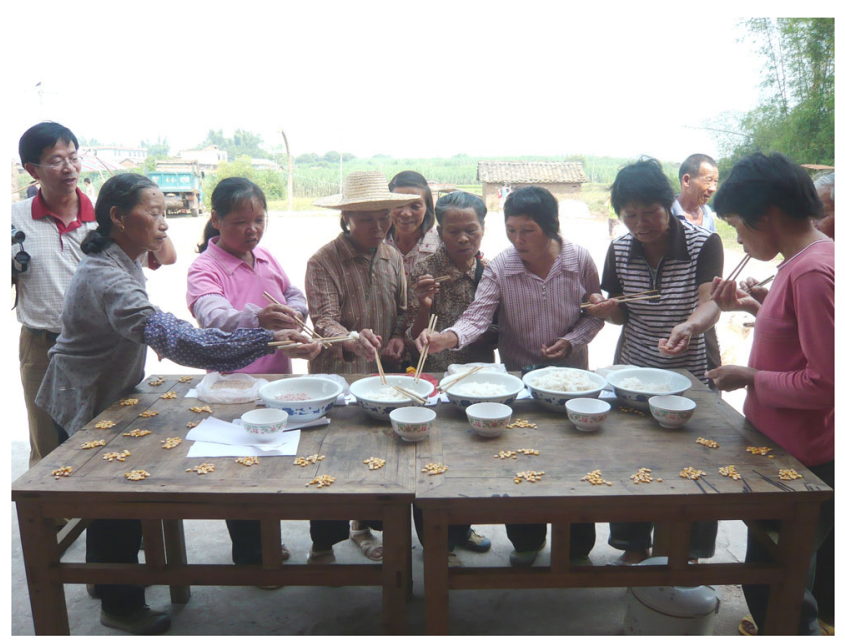

Fig. 2 Societal resilience of rice. Chinese female farmers rank the quality of rice prepared from different cultivars based on their culturally determined preferences and allocating a certain number of maize kernels to indicate the rank of preference. Rice cultivars play an important role in local food and seed sovereignty. Picture by Edith T. Lammerts van Bueren shows equally long root systems for the water-deficit treatment and the control. Material and data from an experiment described by Kadam et al. (2017). Reproduced with kind permission from Dr. Niteen N. Kadam, International Rice Research Institute and Wageningen University \& Research

resources. The rapid increase in technological opportunities in the primary process of creating genetic variation and breeding material that enabled the use of this genetic variation and the testing of new breeding material increased the costs of bringing new cultivars to the market and changed the playing field for breeders drastically in a very short time.

These developments had several disadvantages or negative side-effects. For example, many useful crops with a relatively small acreage became orphans for which breeding is no longer carried out (Gepts and Hancock 2006; Khoury et al. 2014; Bradshaw 2017), thus increasing the dependence of the world food system on a limited number of crops (Khoury et al. 2014). Moreover, the policy and governance rules involved in variety testing protocols, variety registration, and on-farm seed saving, once developed to protect the seed users (farmers), now more and more seem to develop into institutions that protect the interests of the breeding industry (Louwaars et al. 2011; Braunschweig et al. 2014).

These developments triggered resistance from societal organizations: breeding has become contested, for example for reasons of social justice, food sovereignty, ownership of genetic resources, farmers' rights on seed saving (seed sovereignty), patenting of plant material, climate-robust traits and genes, improvement of small crops to maintain crop diversity, acceptance of novel breeding techniques, the mergers and monopolies of large multinationals, and the package deals of genetic modification (GM) technology associated with the use of pesticide 
Fig. 3 Roles and positioning of the breeding and seed systems within their technical, economic, institutional and cultural context

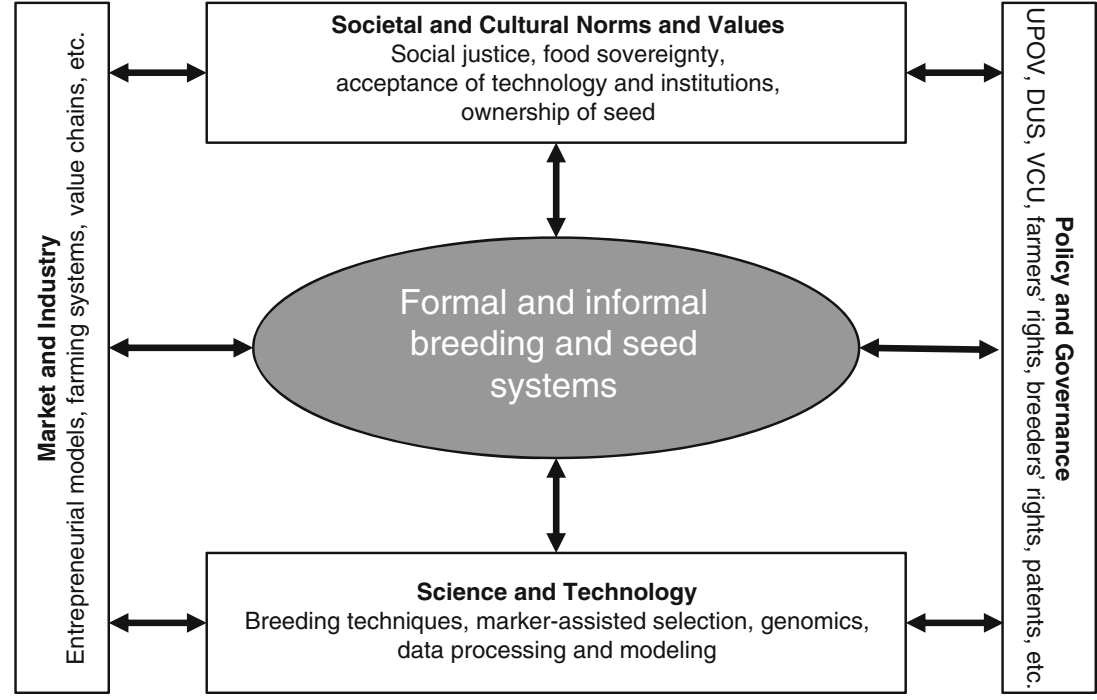

resistant cultivars (Madsen and Sandøe 2005; Halewood et al. 2007; Waltz 2009; Jacobsen et al. 2013; Ceccarelli 2014; De Schutter 2014; Lucht 2015; Nuijten et al. 2017a).

Seeds are an essential element, not only of our food systems but also of our culture and society as a whole. Therefore, plant breeding should be in the center of the societal debate on the future of agriculture. However, a debate on the role of plant breeding in an integrated approach to meet the policy targets on ecological and societal resilience of agriculture as a whole is noticeably lacking. In the next section, we analyze the different positions (or "orientations") in the breeding and seed sector and argue that there is a need for change to enhance the contributions of plant breeding towards ecological and societal resilience.

\section{Diverse orientations in plant breeding and the seed sector}

To define the different orientations of plant breeding, we developed an analytical framework based on Bawden's framework of worldviews (Bawden 2010). Figure 4 illustrates four

\begin{tabular}{c|c}
\multicolumn{2}{c}{ Holism } \\
$\begin{array}{c}\text { Community-based } \\
\text { breeding }\end{array}$ & $\begin{array}{c}\text { Ecosystem-based } \\
\text { breeding }\end{array}$ \\
\cline { 2 - 3 } Subjectivism Objectivism \\
$\begin{array}{c}\text { Corporate-based } \\
\text { breeding }\end{array}$ & $\begin{array}{c}\text { Trait-based } \\
\text { breeding }\end{array}$ \\
Reductionism
\end{tabular}

Fig. 4 Four breeding orientations as functions of different positions between subjectivism and objectivism, and between holism and reductionism breeding orientations originating from different combinations of subjectivism and objectivism on the one hand, and of holism and reductionism on the other hand. These four combinations, termed "paradigmatic positions," have different styles of thought as visualized in the four quadrants of Fig. 4 and are called: (1) community-based breeding, (2) ecosystem-based breeding, (3) trait-based breeding, and (4) corporate-based breeding. Community-based breeding can be considered as a search for restoring or renewing alliances as part of local, innovative food systems supporting food sovereignty and cultural diversity. Ecosystem-based breeding supports developing varieties adapted to various pedo-climatic growing conditions at regional level. Corporate-based and trait-based breeding orientations constitute the currently dominant, reductionist style of thought in most industrialized countries and are represented by their commercial breeding multinationals and breeding research institutes. Corporate-based breeding aims to meet particular wishes and needs of the market, whereas trait-based breeding departs from the notion what kind of crops society needs to boost future crop production, and aims to dig deeper into the genetics behind the underlying traits. Whereas the two paradigmatic positions on the left of Fig. 4 are driven by subjective goals of commercial companies (corporate-based breeding) or communities (communitybased breeding), the two paradigmatic positions on the right of Fig. 4 are driven by objective goals that support better performance of crops by disentangling traits (trait-based breeding) or by matching cultivars to the right environments (ecosystem-based breeding).

Below we will describe the four paradigmatic positions in more detail. To support these descriptions, we have added Table 1, which provides an overview of our perception of the specific characteristics of each breeding orientation with respect to the institutional philosophy and related norms and values, socio-economic aspects, breeding technology, legal aspects, 


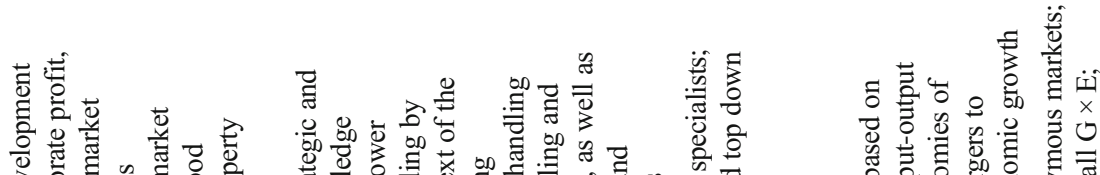

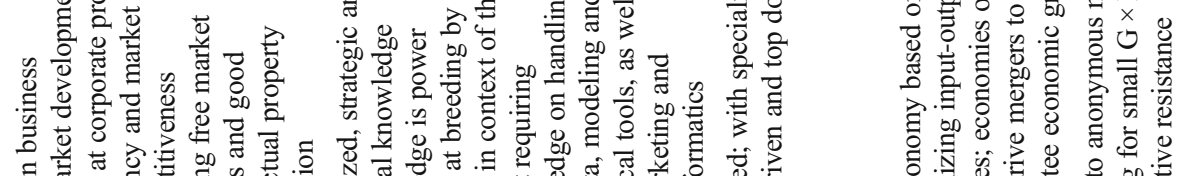

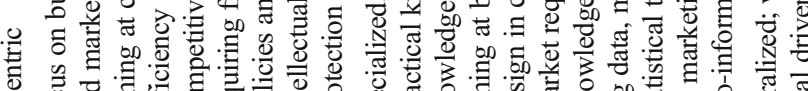

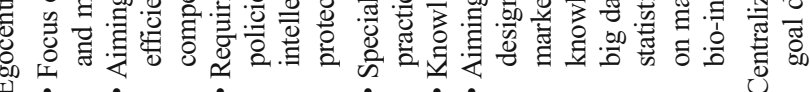

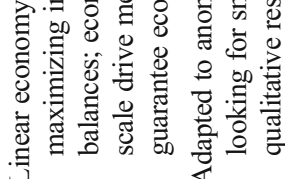

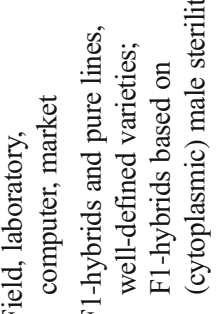
西

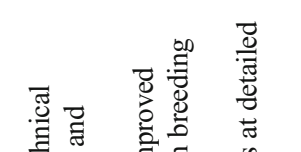

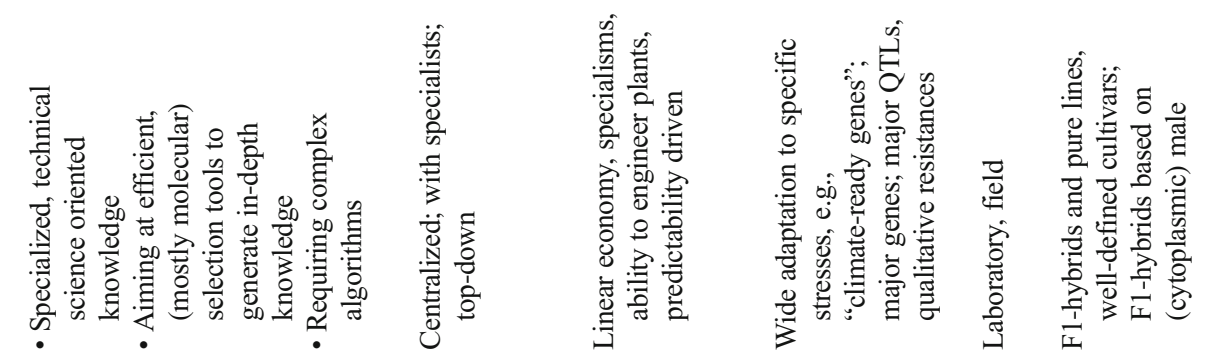

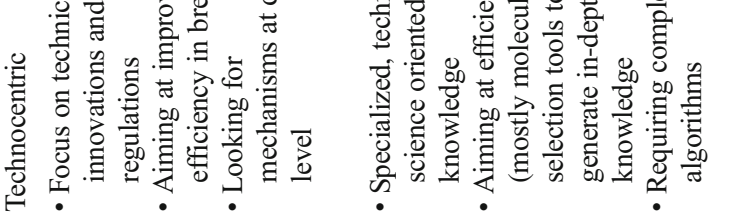

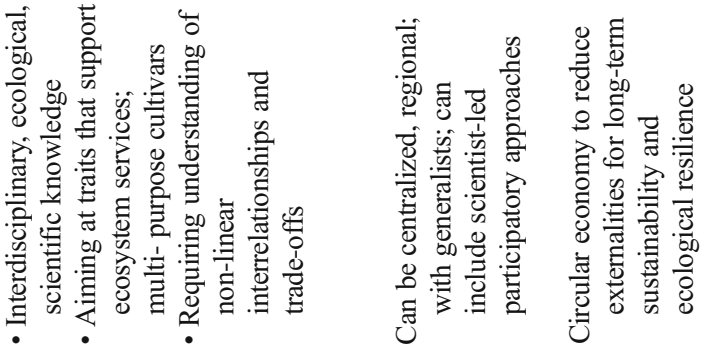
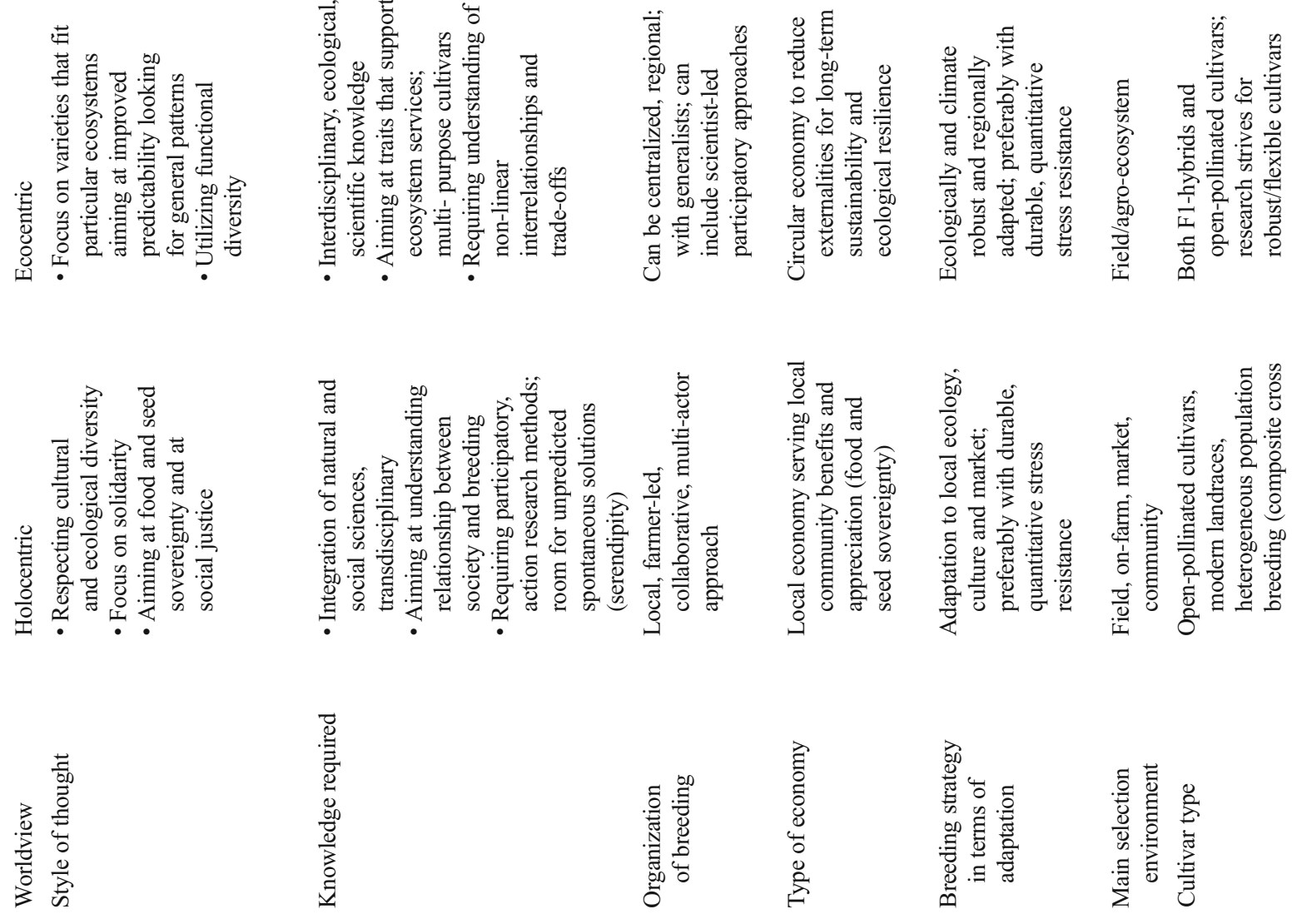

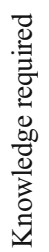
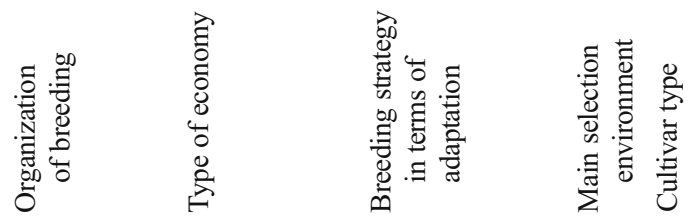


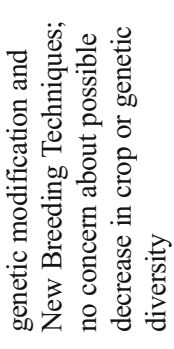

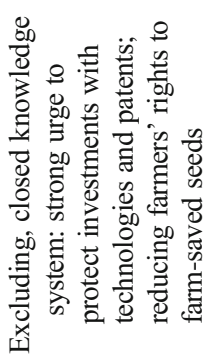

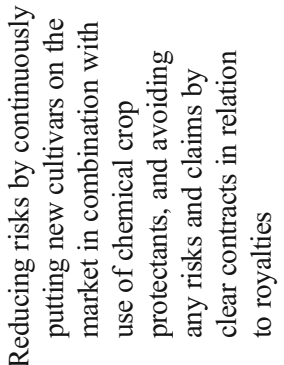

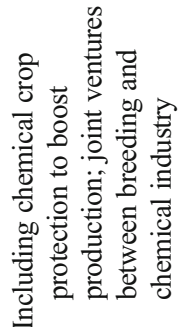

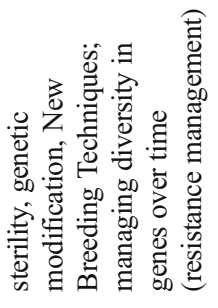

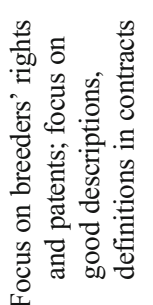

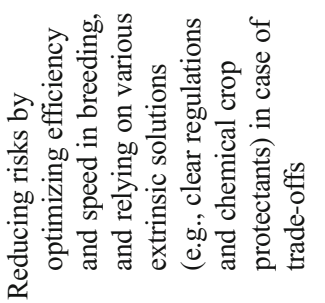

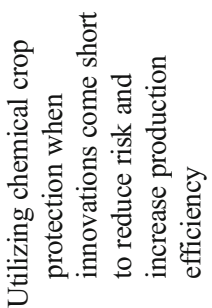

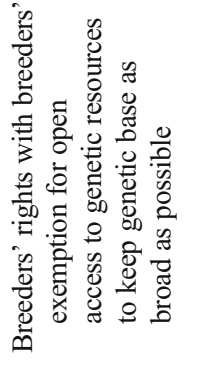

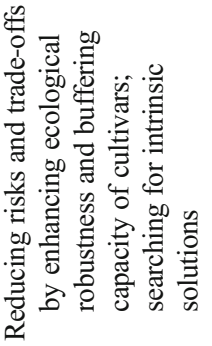

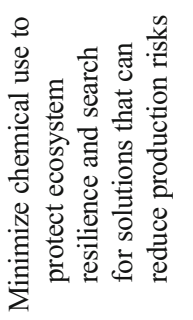

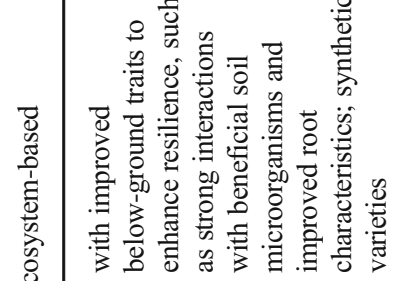
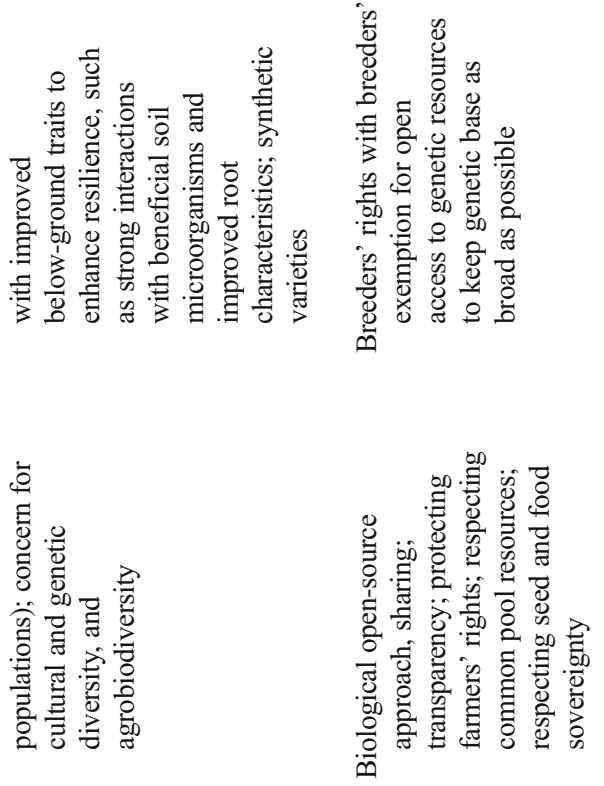

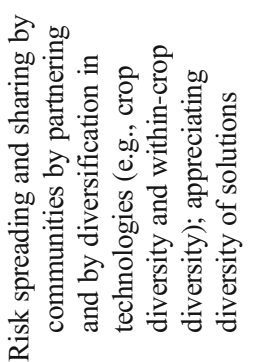
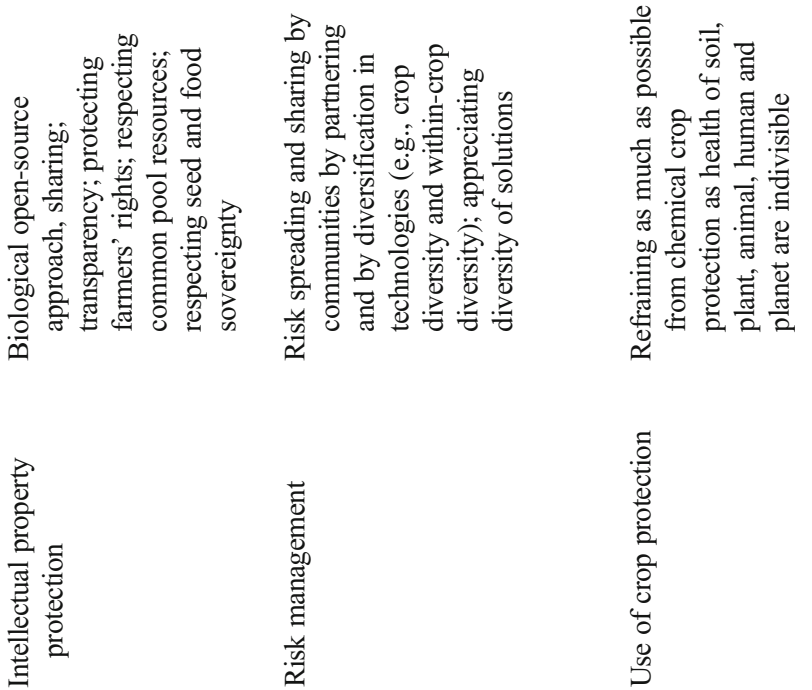

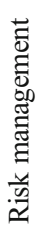

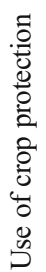

$\begin{array}{ll} & \\ 0 & 0 \\ 0 & 0 \\ 0 & 0 \\ 0 & 0 \\ 0 & 0 \\ 0 & 0 \\ 0 & 0 \\ 0 & 0 \\ 0 & 0\end{array}$


and risk management. Table 2 summarizes the strengths and potential weaknesses of each breeding orientation.

\subsection{Community-based breeding}

In the upper left quadrant of Fig. 4, the community-based breeding orientation is a style of thought that combines holism and subjectivism. It aims to develop collaborative breeding networks and organizations involving a range of chain players at local or regional level, thereby respecting diverse cultural values and societal pluriformity (see Fig. 4 and Table 1). Hence, this breeding orientation serves both cultural diversity and agro-biodiversity, maintaining and developing a diversity of (orphan) food crops and varieties, but also emphasizing food and seed sovereignty of these communities and seed as common good (Kloppenburg 2010; Wirz et al. 2017). In developing countries, it represents breeding by local communities anchored in local economies, in many cases supported by regional NGOs and research institutes, such as the MASIPAG (FarmerScientist Partnership for Development) initiative in the Philippines (Bachmann 2010) and various Campesino a Campesino initiatives in Latin America, such as the National Association of Small Farmers (ANAP) in Cuba (Rosset et al. 2011); and it often results in empowerment of local farmer communities and sometimes more specifically women farmers (see, e.g., Almekinders 2011; Li et al. 2014; Galiè et al. 2017). In the context of the industrialized world, this breeding orientation uses multi-actor approaches, involving farmers, processors, traders, restaurant chefs, and consumers. There is an increasing number of examples of such multi-actor approaches organized or supported not only by NGOs in industrialized countries enhancing breeding for regional varieties adapted to local circular economies, such as the Organic Seed Alliance in the USA (www.seedalliance.org), Rete Semi Rurali in Italy (Campanelli et al. 2015), and Réseau Semences Paysannes in
France (Desclaux et al. 2008), but also supported by publicly funded research projects at research institutes and universities, such as NOVIC in the USA and Canada (Shelton and Tracy 2015), and SOLIBAM (www.solibam.eu), DIVERSIFOOD (www.diversifood.eu) and LIVESEED (www.liveseed.eu) in the EU. This "holocentric" orientation requires development of appropriate methods of breeding, experimental designs, and variety selection that fit the local, multi-faceted complexity of the social and physical environment and create sustainable and tailor-made solutions for local actors. Actors strive for ways to realize seed sovereignty involving seed types that farmers can easily reproduce or improve (e.g., open-pollinated cultivars, landraces, and heterogeneous populations) and advocate farmers' rights for use of farm-saved seed (see, e.g., Fitzgerald 1993; Kloppenburg 2010).

To create more buffering capacity and yield stability in low-input farming systems, the concept of heterogeneous populations, also called composite cross populations originating from evolutionary breeding, is currently further developed by various breeders active in the organic sector (Murphy et al. 2005; Ceccarelli et al. 2010; Döring et al. 2011; Murphy et al. 2016; Brumlop et al. 2017; Raggi et al. 2017). These types of populations are characterized by a high level of genetic diversity, as they consist of a mixture of many different genotypes, often with complementing below- and above-ground traits.

The phenotypes and genotypes of these diverse populations are very heterogeneous and can evolve over time under the selection pressure of the environment (evolutionary breeding), as they will adjust to changing growing conditions (as under climate change) when farmers continue to save seeds on-farm. Although less diverse, farmer-developed open-pollinated cultivars and landraces also have the potential to adapt to changing growing conditions. Such diverse reproductive material does not comply with the commonly applied criteria for variety registration based on homogeneous varieties, and can

Table 2 Strengths and potential weaknesses of the four breeding orientations

\begin{tabular}{|c|c|c|c|c|}
\hline & Community-based breeding & Ecosystem-based breeding & Trait-based breeding & Corporate-based breeding \\
\hline Strengths & $\begin{array}{l}\text { - Integrative approach } \\
\text { - Solidarity } \\
\text { - Focus on collaboration } \\
\text { - Respecting cultural values }\end{array}$ & $\begin{array}{l}\text { - Ecological-systematic approach } \\
\text { - Long-term perspective } \\
\text { - Generalists } \\
\text { - Serving ecosystem services }\end{array}$ & $\begin{array}{l}\text { - Analytical-systematic approach } \\
\text { - Detailed in-depth knowledge } \\
\text { - Specialists }\end{array}$ & $\begin{array}{l}\text { - Entrepreneurial } \\
\text { - Competitive } \\
\text { - Expertise in value chains } \\
\text { - Clear business model } \\
\text { - Ability to make large } \\
\text { steps forward }\end{array}$ \\
\hline $\begin{array}{l}\text { Potential } \\
\text { weaknesses }\end{array}$ & $\begin{array}{l}\text { - Too small scale to ensure } \\
\text { continuity } \\
\text { - Inward focus } \\
\text { - Too much focus on all } \\
\text { complex relationships, not } \\
\text { being able to move forward } \\
\text { - Conservative and afraid of } \\
\text { (socio-technical) innovation } \\
\text { - Difficult to scale up/out }\end{array}$ & $\begin{array}{l}\text { - Difficult to connect to } \\
\text { currently dominant } \\
\text { business model } \\
\text { - Complex } \\
\text { - Long-term profit orientation } \\
\text { - Too broad and forgetting } \\
\text { in-depth analysis } \\
\text { - Forgetting the outliers } \\
\text { - Forgetting the people }\end{array}$ & $\begin{array}{l}\text { - Not always in connection } \\
\text { with pluriformity in society } \\
\text { - Too much focus on details } \\
\text { and molecular oriented } \\
\text { - Costly and thus dependent } \\
\text { on patenting for return on } \\
\text { investments } \\
\text { - Dependent on industry for } \\
\text { investments }\end{array}$ & $\begin{array}{l}\text { - Too much driven by short } \\
\text { term profit and the } \\
\text { market } \\
\text { - Mergers at the cost of } \\
\text { diversity of players and } \\
\text { crops } \\
\text { - Path dependencies leading } \\
\text { to monopoly } \\
\text { - Lack of transparency and } \\
\text { solidarity }\end{array}$ \\
\hline
\end{tabular}


therefore not be marketed in Europe without adaptation of the variety registration protocols. The European Commission is currently experimenting by providing derogations to test and market heterogeneous populations of cereals (wheat, barley, oats, and maize) in six EU countries (Cuoco 2017).

The strengths of this orientation include the attitude of seeking solidarity and collaborative and integrative breeding approaches (Table 2). As the approach includes a transparent, bottom-up approach, the trade-offs and risks are known and shared among the community members. Moreover, farmers and other value chain actors feel empowered by communitybased approaches. A weakness can be that the activities are too small-scaled and that upscaling is difficult, partly due to their specific local embeddedness and partly due to political and institutional constraints. There are opportunities to link formal and informal breeding approaches when policies start to support the development of community-based, collaborative breeding organization structures as is aimed for in the various above described projects.

\subsection{Ecosystem-based breeding}

The ecosystem-based breeding orientation (in the upper right quadrant) starts from an ecological perspective and is a style of thought that combines holism and objectivism analyzing general patterns in ecology and aiming at developing varieties adapted to ecological conditions at regional level (see Fig. 4 and Table 1). In the late $1980 \mathrm{~s}$, participatory plant breeding started to develop in response to the Green Revolution where between the 1960 to 1980 s technology packages (new cultivars responding to high external inputs) were introduced, overlooking the ecological risks of high-input farming and ignoring the needs of subsistence farmers in many remote and harsh environments. There was a need for better matching cultivars with local pedo-climatic and socio-cultural conditions and therefore enhancing yield stability and food security, and empowering farmers (e.g., Bänziger and Cooper 2001; Ceccarelli et al. 2001; Almekinders and Hardon 2006; Galiè et al. 2017).

Currently, this orientation more and more departs from the notion that there is a need to enhance productivity without harming the environment and taking care of sustainability of the agroecosystems (Rockström et al. 2009; Struik and Kuyper 2014). The acknowledgment of potential ecological risks leads to the need to manage risks through both external inputs and intrinsic solutions, such as enhancing ecological robustness and buffering capacity of cultivars (Murphy et al. 2014). Relatively recent breeding research is being developed to also include long-term goals, such as contributions to the maintenance or restoration of ecosystem services as targets in breeding programs. For example, breeding will deliver cultivars that are attractive for pollinators (Suso et al. 2016), contribute to accumulation of soil organic matter (De Deyn et al. 2008; Deru et al. 2014), enhance the biodiversity in the soil (Perez et al. 2017), or increase the nutrient use efficiency at the ecosystem level (Gilbert 2016; Lammerts van Bueren and Struik 2017).

This "ecocentric" orientation puts durable sustainability and ecological resilience up front taking into account the complexity of environmental factors influencing crop growth and ecosystem functioning. This orientation can benefit from knowledge on ecological relationships, for example the interactions of crop plants with beneficial soil organisms, such as mycorrhizas, to enhance efficient nutrient uptake (Gewin 2010; Galván et al. 2011), from knowledge on physiological processes affecting traits contributing to nitrogen use efficiency (Lammerts van Bueren and Struik 2017), and from knowledge on plant plasticity under climate change leading to irregular weather patterns (Nicotra et al. 2010). Typically, breeding initiatives in this orientation are funded publicly or through international institutions.

The strengths of this orientation are the long-term holistic perspective and the focus on ecosystem health, and sustainability and on balancing trade-offs (Table 2). However, this breeding approach includes complex traits and requires many years of experience to acquire in-depth and site-specific knowledge and innovative tools for effective selection. Breeding technologies used include field-level observations and selection activities. The weakness of this orientation is that cultural and socio-economic specificities can easily be overlooked; participatory approaches are considered by the formal breeding sector for niches, such as for organic agriculture or subsistence farmers in developing countries. For instance, breeding climate-robust cultivars is not just a technical quest, but also the local, ecological, and socio-cultural context should be integrated to obtain cultivars that are regionally adapted and will be adopted.

Another concern is that in the current breeding systems, short-term return of investments is dominating and usually business cases for long-term sustainability goals (such as breeding for ecosystem services) do not yet exist. This requires incorporating true-cost accounting on the production and impact of cultivars promising high yield but at the cost of natural resources. Investments in research on complex traits serving long-term sustainability should deserve higher priority for financing by green policies.

\subsection{Trait-based breeding}

The trait-based breeding orientation is a style of thought that combines objectivism with reductionism, resulting in a mechanistic view of how plants grow (see Fig. 4 and Table 1). Louwaars (2018) argues that the term "trait breeding" becomes increasingly valid because the detailed knowledge of the genome allows high levels of precision, a close relation between genotype and phenotype, and minimal linkage drag. Crop physiology and genomics support such an approach to better understand how plants grow and how to improve them, 
by subdividing complex traits into smaller, manageable (heritable) components and by better understanding how these components contribute to plant traits, such as salt or drought tolerance, and how they are regulated (see, e.g., Yin et al. 2004; Munns and Richards 2007). Nowadays, efforts have been made to improve the efficiency of field-based selection with increased controllability and predictability, such as with the design of early generation variety trials with correlated data and high-throughput phenotyping methods (e.g., Cullis et al. 2006; Deery et al. 2016).

This more "technocentric" orientation departs from the notion that plants are composed of genes that can be switched off (or downregulated) in case of undesired traits or switched on (or upregulated) in case of desired traits (Cardi and Stewart 2016; Mahfouz et al. 2016). Today, trait-based breeding is associated with molecular techniques and high-throughput, high-tech phenotyping systems that collect massive data sets that are used for genome-wide association studies, often supported by novel approaches of big data analysis, advanced statistical approaches and modeling exercises. Favorable traits can also be included or reorganized by design, for example through genetic engineering techniques (Koornneef and Stam 2001; Cooper et al. 2014; Haverkort et al. 2016; Bradshaw 2017). Very specialized sciences, such as molecular biotechnology, molecular genetics, and various -omics disciplines, play an important role to support the breeding-by-design approach (Peleman and Rouppe van der Voort 2003). Much of this modern technology-driven breeding research is conducted at both universities and multinationals with public and corporate funding.

The strengths of this orientation are the creation of new, indepth knowledge of traits, their regulation, and the relationships between genetics and crop physiology (Table 2). But this breeding orientation with its emphasis on technical solutions for complex questions can easily lead to blind spots: knowledge development is very much focused on the commercial breeding industry for large-scale farming systems and less attention is paid to other breeding models that can be applied by small-scale breeders or farmer communities, or to developing strategies for more diversified food systems (see, e.g., Lammerts van Bueren et al. 2010; Ceccarelli 2014; Dwivedi et al. 2017). Simultaneously, this approach has difficulties to relate the technical knowledge with the broader agro-ecological and socio-economic context. Similar to ecosystem-based breeding, trait-based breeding has the risk to focus merely on technical solutions and to be less oriented on specific cultural aspects, norms and values. Another weakness is the fact that capital investments in technology developed by companies or research institutes are high and that patents play an important role, not only as intellectual property protection but also to generate quick return of investments (Table 2). Today, publishing results of publicly funded breeding research is often delayed until after patents have been secured.

\subsection{Corporate-based breeding}

The corporate-based orientation is a style of thought that combines subjectivism and reductionism (see Fig. 4 and Table 1). It assumes that the truth and knowledge on what is best are relative and are up to the individual or corporate organization (i.e., "egocentric" view according to Bawden 2010). Similar to trait-based breeding, corporate-based breeding assumes that complexity can best be understood and dealt with by analyzing and breaking down complex crop characteristics into underlying single, manageable components and by specializing in those components that serve the company's interests best. In that sense, the corporate-based breeding orientation often makes use of trait-based approaches. Corporate-based breeding is primarily focused on the continuity of the business and has to cope with competition, resulting in market-driven firms, which concentrate on those crops or globally adapted cultivars that provide the best profit. Corporate breeding companies may range from very small companies operating at national level to multinational companies operating at international level (Barnes et al. 2016). Essential in this orientation is the goal-driven, linear-economy thinking, including a top-down organization of the breeding and seed production activities.

There is an increasing need for a quick return on investments, making it necessary to protect the intellectual properties with patents on (parts of) the technology developed as is common in other industries (Howard 2015). It also leads to the application of breeding methods that create "natural" (biological) barriers to prevent the competitor to easily copy or multiply, such as is realized by incorporating the (cytoplasmic) male sterility trait in F1-hybrids. It also drives the policy to adopt seed regulations such as UPOV 1991 where farmers' rights for on-farm seed saving are strongly restricted compared to the farmer-friendly former version UPOV 1978 (Braunschweig et al. 2014). There are also concerns about the mergers of the seed industry with the chemical industry resulting in forcing combined use of specific cultivars and crop protectants (Howard 2009).

The economies of scale are important drivers leading to a reduction of diversity in crop portfolio, mergers or consolidations to acquire economic vitality (Lindner 2004; Howard 2009). The research and development investments in corporate breeding companies are high (up to $35 \%$ of the yearly turnover) and the willingness of sharing knowledge with other players in the breeding sector is strongly reduced, which results in a lack of transparency (Barnes et al. 2016). The costs of investment increase as the lifespan of cultivars on the market becomes shorter. As diversity is key to food security and sovereignty, there is a need for green policies to allow diverse and local farmer participatory breeding programs to address small crops neglected in breeding (Khoury et al. 2014; Khoury and Jarvis 2014). 
The strengths of corporate-based breeding include its entrepreneurship and innovative competiveness, and its emphasis on the market and value chain (Table 2). Simultaneously, these strengths also induce a narrow-mindedness and path dependency that should be classified as clear weaknesses. The increased focus of the corporate-based breeding orientation on the economic and legal value of seed as a commodity increases the tension with the drive in the community-based breeding orientation for developing open-source seed system models acknowledging the cultural value of seed including common good aspects, as described by Wirz et al. (2017).

\subsection{The need to combine potentials of the four paradigmatic orientations}

Given the need to create ecological and societal resilience, these four breeding orientations each have their strengths and weaknesses (Table 2). They also have different values leading to different choices and decisions on trade-offs and risks (Table 1), none being inherently good or bad. Each understands, interprets, and operationalizes the six international breeding targets discussed in the introduction (agrobiodiversity; ecosystem services; climate robustness; food security, safety and quality; food and seed sovereignty; and social justice) in different ways. However, none of them alone can fully and whole-heartedly contribute to the realization of a productive, truly sustainable agriculture combining all those six targets. In reality, many, if not all, breeding organizations, companies, institutes, and societal initiatives integrate, often tacitly, various aspects of two or more quadrants (see also the interactions shown in Fig. 3). Some initiatives have been aiming to integrate purposefully several aspects of two or more quadrants (for example, Ceccarelli et al. 2001; Sperling et al. 2001). An interesting recent example that combines strengths of various quadrants is a case in China where F1-hybrids of maize were developed in a participatory program for the farmer fields in the more fertile valleys next to open-pollinated varieties for their rain-fed mountain fields; the institute breeders gave the farmers access to the parent lines and taught involved farmers how to propagate the F1-hybrid seed for sales to their local farmers' market. In this way, F1hybrids can serve smallholders while care is taken to secure their seed sovereignty ( $\mathrm{Li}$ et al. 2013). Another example is the Dutch Bioimpuls program for the collaborative development of phytophthora resistant potato varieties where organic farmer breeders, commercial breeders and scientists work together. The scientists develop new germplasm to be further tested and selected by both farmer breeders and commercial breeders. Interesting selections by farmer breeders can be put on the market by the commercial breeders (Lammerts van Bueren et al. 2014).

However, these initiatives are not integrating the six sustainability targets to such an extent that all six can be substantially met. Also, these initiatives often meet various institutional hurdles preventing them to become part of mainstream breeding. And importantly, the relative size of these initiatives is limited compared to the size of the commercial breeding sector that is mainly situated in the lower two quadrants (corporate-based and trait-based breeding). In other words, a balance is needed between the efforts in the four quadrants.

To overcome the gaps that exist in the current breeding sector as a whole, it is necessary to capitalize on the emergent benefits of the positive interactions between the diversity of breeding models, breeding technologies and business models operating in a diversity of biophysical environments and at the same time dealing with a diversity in the societal aspects of our food systems. But it is also necessary to do more than combining the strengths and valuable assets of the different paradigmatic positions. To fulfill not only short-term needs of an increasing world population but also long-term societal and ecological resilience, integration of all four breeding orientations is urgently required, and this will not happen by itself. The commitment of cooperatives, institutions, society, and governments towards or the tendency to feel responsible for the long-term sustainability of society and agroecosystems is low, and thus, there is no urge to pay attention to sustainability measures that might increase costs on the short term but can ensure long-term sustainability of the planet and society, unless governments set boundaries and enforce new rules for creating a level playing field for all actors.

To meet the ambitious goals to ensure societal and ecological resilience at the same time, a more explicit type of thinking is required in the form of an overarching, integrative, fifth style of thought: systems-based breeding. This systems-based breeding orientation should provide a common future vision as a guide maintaining a balance between the four quadrants and, consequently, for a diversity of breeding approaches and activities that complement each other rather than a blueprint for one scheme. The systems-based breeding orientation should maximize the synergy between the strengths of community-based, ecosystem-based, trait-based and corporatebased breeding approaches, and develop innovative ways of organizing plant breeding and establishing stronger interactions between all components of the system to meet the future challenges as described in the introduction. This will be elaborated in the next section.

\section{Defining a systems-based breeding orientation}

In the envisioned concept of systems-based breeding, "system" is defined as the space that encompasses the civil society (with its diversity of cultural norms and values), policy (with various governance institutions), nature (including the 
diversity of pedo-climatic conditions and habitats), agriculture (including the diversity of agro-ecosystems and farming systems), and value chains and markets as interrelated and mutually dependent components of the entire system (as shown in Fig. 3). Systems-based breeding aims to integrate various paradigmatic positions, but not to merge them. Systems-based breeding should be a style of thought that is systems-centric, both by its focus on holistic policy targets as well as by its methodology integrating holistic and reductionist approaches. The paradigm shift requires systems thinking of all actors involved, acknowledging that all parts and players in the system are interrelated and are affecting each other, and that all players need to commit themselves to a collective learning process to achieve this shift over the course of time (Senge 2006).

To define the systems-based breeding orientation, we will identify and discuss key aspects of required change in attitude (corporate social responsibility, circular economy and true-cost accounting, fair and green policies), the process from attitude to action (knowledge development and integration, breeding strategies and tools, entrepreneurship), and the process from action to achievement (food security, safety and quality; food and seed sovereignty; social justice; agrobiodiversity; ecosystem services; and climate robustness). These three areas will be discussed below and are summarized in Table 3 and Fig. 5.

\subsection{Required change in attitude}

To allow all players to adopt systems thinking, there is a change in attitude required, not only from the private businesses but also from citizens and policy makers. There are already starting points to build on, such as corporate social responsibility, circular economy and true-cost accounting, and fair and green policies, but efforts will need to be intensified in the context of the systems-based breeding orientation.

Corporate social responsibility (CSR) is a form of corporate self-regulation, integrated into a business model, monitoring and ensuring its active compliance with the spirit of the law, ethical standards and national or international norms (Knowles 2014). It requires ethical, philanthropic, legal, and economic responsibilities, but also leadership, personal responsibility, and trust (Mostovicz et al. 2011). CSR within a breeding company could entail balancing people, planet, and profit, respecting diversity of societal norms and values, while interacting with society to enhance choice and appreciation of breeding approaches and produce supporting sustainability.

An important aspect of sustainability is the circular economy that should go beyond a regenerative system in which resource input and waste, emission, and energy leakage are minimized by slowing, closing, and narrowing material and energy loops as the social feedback loops are missing (Geißdörfer et al. 2017). Van der Weijden et al. (2012) considered it a precondition for an integrated sustainable food production system to move away from the linear organized production chain based on specializations where crucial relationships have gone lost or have become corrupted. Only when there is an overall agreement in the chain of the common goals of sustainability, externalities will be prevented; so rebuilding relationships in the value chain into food networks, and interweaving ecology, society, sustainable agriculture and healthy food are key. In such new relationships, true-cost accounting can contribute to enhance transparency about hidden costs by showing the ecological and social (health and justice) costs made and the benefits realized during production, storage, processing, transport, marketing, etc. This is now being implemented for food products by several food organizations (see, e.g., Holden 2013; Eosta et al. 2017).

The term "fair and green policies" underlines that sustainable food production and consumption need to be embedded and enhanced by good governance and policies to create a level playing field for all players and a legal and economic framework for long-term green and fair innovation. For example, most companies are specialized in a specific assortment of the main crops and value chains. Government policies should stimulate a diversity in initiatives, not only to stimulate breeding for small crops and markets (Khoury and Jarvis 2014), but also to stimulate different breeding approaches for the main crops. An example is enhancing sustainability by making use of genetic diversity, such as multiline breeding (Groenewegen 1977; Mundt 2002) or evolutionary breeding, as is currently applied in the organic sector with composite cross populations (Döring et al. 2011). This requires adaptation of the variety registration based on the so-called DUS (distinctness, uniformity, and stability) protocols accepting heterogeneous material instead of only departing from homogeneous pure lines (Louwaars 2018).

\subsection{From attitude to action}

Capra (1997) suggested that people need to understand the principles of the organization of ecosystems and need to become "ecoliterate" to create sustainable human communities. To achieve that, shared and reflective learning is needed to reconnect people and food (King 2008). King and Powell (2000) indicated that ecological and societal resilience encompasses plasticity, also in non-equilibrium systems, but also the capacity to co-evolve and co-learn, managing cyclical patterns and non-linear processes with multi-stakeholder teams.

Plant breeding and seed production can only successfully contribute to the systems-based breeding targets (see Section 4.3) when this vision of a coherent and system-centric breeding concept is shared and nurtured. This process not only requires respect for the pluriformity in society but also empowerment of diversity of approaches to reach ecological and societal resilience. It requires a diversity of actions from various groups in a pluriform society: (i) knowledge development and integration, (ii) development of a multitude of breeding strategies and tools, 
Table 3 Key elements and aims of the systems-based breeding orientation

\begin{tabular}{|c|c|c|}
\hline & Key elements & Aims \\
\hline \multirow[t]{3}{*}{ Required change in attitude } & Corporate social responsibility & $\begin{array}{l}\text { Including ethical and social responsibilities beyond } \\
\text { legal and economic responsibilities }\end{array}$ \\
\hline & Circular economy and true-cost accounting & $\begin{array}{l}\text { Rearranging linear relationships such that value } \\
\text { chains become value networks in which various } \\
\text { actors work together }\end{array}$ \\
\hline & Fair and green policies & $\begin{array}{l}\text { Creating a frame work for optimal integration of all } \\
\text { components of systems-based breeding }\end{array}$ \\
\hline \multirow[t]{3}{*}{ From attitude to action } & Knowledge development and integration & $\begin{array}{l}\text { Supporting continuous development of specialized, } \\
\text { generalized and integrated knowledge at various } \\
\text { levels (socio-economic, agro-ecological, etc.) }\end{array}$ \\
\hline & Breeding strategies and tools & $\begin{array}{l}\text { Designing a range of different appropriate technical } \\
\text { breeding approaches }\end{array}$ \\
\hline & Entrepreneurship & $\begin{array}{l}\text { Developing sound entrepreneurial models suitable } \\
\text { for various small and large value chains }\end{array}$ \\
\hline \multirow[t]{6}{*}{ From action to achievement } & Food security, safety, and quality & $\begin{array}{l}\text { Enhancing breeding of food that is healthy, nutritious } \\
\text { and safe, with high and stable yield, and good } \\
\text { shelf-life that does not require chemicals during } \\
\text { production and storage }\end{array}$ \\
\hline & Food and seed sovereignty & $\begin{array}{l}\text { Allowing a pluriformity of breeding models to } \\
\text { co-exist and for communities and markets to } \\
\text { choose breeding models that fit best, implicitly } \\
\text { serving cultural diversity and seeds as } \\
\text { common good }\end{array}$ \\
\hline & Social justice & $\begin{array}{l}\text { Fair and just assigned rights and duties in relation to } \\
\text { breeding activities and products, such as breeders' } \\
\text { privilege, farmers' rights and fair prices for (farmer) } \\
\text { contract seed producers }\end{array}$ \\
\hline & Agrobiodiversity & $\begin{array}{l}\text { Enhancing agro-biodiversity in farming systems; } \\
\text { within and among crop species; improve diversity } \\
\text { in major and small crops }\end{array}$ \\
\hline & Ecosystem services & $\begin{array}{l}\text { Improving breeding strategies, breeding products and } \\
\text { crop traits that support ecosystem services }\end{array}$ \\
\hline & Climate robustness & $\begin{array}{l}\text { Creating climate robust and flexible breeding strategies } \\
\text { and products that provide yield and quality stability } \\
\text { under variable conditions }\end{array}$ \\
\hline
\end{tabular}

and (ii) entrepreneurship. The first action concerns continuous knowledge development and sharing on all aspects of systemsbased breeding, and creating synergy of social and natural sciences necessary to combine sustainability, justice and resilience. A proper integration of specialist knowledge, generalist knowledge, technological choices, and socio-economic and cultural aspects will be crucial. This will require a joint learning process based on transdisciplinarity and action research methods ultimately leading to breeding strategies and tools that contribute to socio-technical innovations at various levels: society, value chain, agro-ecosystem, farm, and trait. Systems-based breeding should be an integrated part of systems innovations in agriculture. Breeding strategies for diversification in agriculture can combine mainstream approaches with those emerging in various research experiments, such as multi-lines (e.g., Henry et al. 2010; Lynch 2011), evolutionary breeding (e.g., Döring et al. 2011; Murphy et al. 2016; Raggi et al. 2017) and breeding for mixed cropping systems (Davis 1989). But many knowledge gaps still exist in implementing such methods in commercial breeding programs, and practical farming and processing practices, and in a legal framework that, for example, allows heterogeneous material to be marketed.

Ideas addressing social justice within the seed business, such as paying contract farmers producing seeds for the corporate companies a fair price, or models that share corporate profit among employees should be further developed. Also, the current initiatives on seed sovereignty in breeding models need to be further explored to identify ways to finance breeding activities other than through royalties of seed sales (Osman et al. 2007; Kloppenburg 2010; Wirz et al. 2017). This requires novel entrepreneurships including all the skills required to develop sound entrepreneurial models in breeding and seed production suitable to diverse small and large value chains and markets (FAO 2016). 


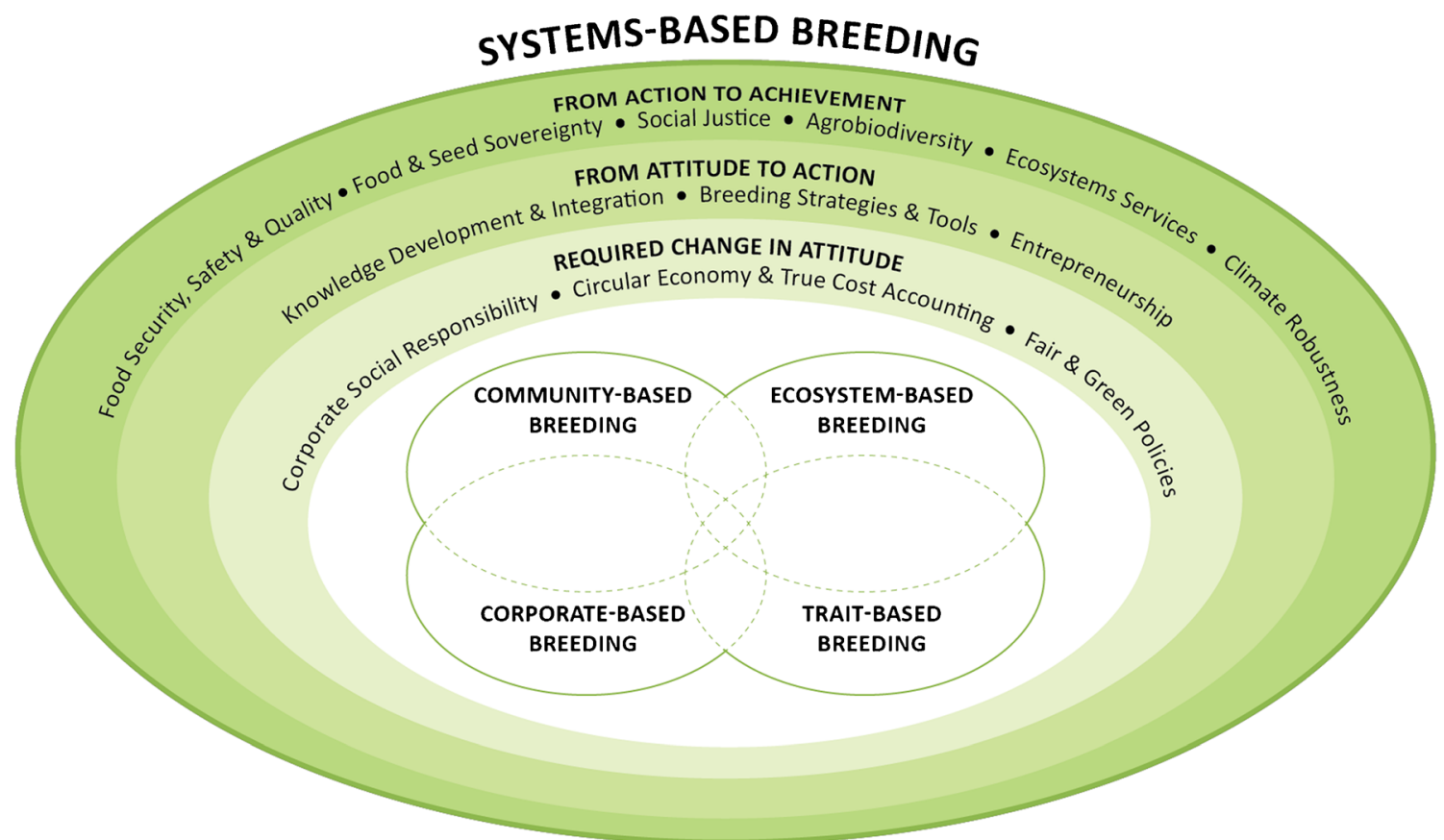

Fig. 5 Representation of systems-based breeding as a fifth, overarching breeding orientation integrating the strengths of the four breeding orientations earlier described

\subsection{From action to achievement}

The aim of systems-based breeding is ecological and societal resilience by combining food security, safety and quality, food and seed sovereignty, and social justice without jeopardizing long-term sustainability of the ecological context by enhancing agrobiodiversity, ecosystem services, and climate robustness. Many of these targets are interrelated. For instance, social justice cannot be realized without environmental sustainability (Coote 2014).

We describe these six targets in terms of breeding goals (see Table 3). For food security, safety, and quality, plant breeding should develop cultivars and populations with high, stable yields of safe, nutritious, diverse food with good storability and shelf-life that do not depend on chemical treatments for good performance. Food and seed sovereignty also means communities should be able to define their own means of production or acquisition and their own preferred food and seed, considering food as a basic human right and seeds as part of common goods (De Schutter 2014; Wirz et al. 2017). De Schutter (2014) also pleads for more support for participatory plant breeding in various crops and regions to meet such goals. Social justice is an important target to contribute to societal resilience and includes the need for plant breeding and seed production to be organized in such a way that fair distribution of wealth, and equal opportunity among communities can be ensured.

To contribute to the long-term ecological resilience in our food systems, agrobiodiversity and ecosystem services should also be addressed by plant breeding. Agrobiodiversity includes not only diversity of crop species but also genetic diversity within crops, to support sustainable and nutritious food production systems and diversity of markets and cultures. It also includes investments in breeding of small crops (Khoury and Jarvis 2014). Ceccarelli (2015) and Coomes et al. (2015) argued that involving various actors in the breeding process supports agrobiodiversity. Ecosystem services regulate and support the environment within agro-ecosystems and sustain future food production and therefore should play a role in agronomy and plant breeding (see, e.g., Huang et al. 2015). Recently, the FAO pictured how livestock species and breeds could contribute to ecosystem services and biodiversity (Hoffmann et al. 2014) but even plant breeders have not internalized ecosystem services yet to a large extent (see Section 3.2). Some of these characteristics related to ecosystem services, such as plasticity of root systems for resource capture, will contribute also to climate mitigation and climate robustness (e.g., Kadam et al. 2017). Climate robustness requires adaptation to variable, unpredictable, and extreme weather conditions tailor-made to local contexts (Shi et al. 2017). The main characteristics of climate robustness are yield stability and plant phenotypic plasticity (Ceccarelli et al. 2010; Nicotra et al. 2010).

\section{Discussion and conclusions}

In this paper, we have made a plea for an integrated approach, which we have coined the systems-based breeding orientation; we propose it as a framework where different approaches related 
to the four quadrants of Fig. 4 can be integrated. A first outline for such a methodological framework, allowing the integration of different approaches, such as, for example, positivism and post-modernism, has been described by Nuijten et al. (2013).

Very recent developments in agriculture have already sown the seeds of this systems-based breeding approach aiming at productivity based on healthy economic performance, transgenerational sustainability and justice, and ecological and societal resilience. Under pressure of consumer organizations, farmers and breeders alike are forced to demonstrate a societally relevant Purpose in addition to serving the needs and concerns of People, Planet, Profit in order to keep their license to operate (Geißdörfer et al. 2017). We have demonstrated that the plant-breeding sector needs to make progress to contribute significantly to Purpose and all its aspects of sustainability, through diverse and complex socio-technical transitions (Geels and Schot 2007). In this section, we will reflect on some critical issues in our concept that were raised in discussions with breeders.

\subsection{Diversity of breeding initiatives and variety registration protocols}

Moving towards systems-based breeding requires multiple processes of co-learning and co-constructing and a diversity of breeding initiatives. Initiatives may start with those willing and eager to become frontrunners to realize examples that create experience on how to overcome obstacles. Initiatives may start from within existing breeding organizations or companies and new initiatives can also start at niche level. Both are important, have different roles and should interact. Initiatives from within the existing breeding sector may have more impact by their size, whereas initiatives starting at niche level can help make significant forward-looking changes. To foster change, fair and green policymaking is crucial. The interplay of the existing sector, the niche and policymaking is important to make a transition to systems-based breeding feasible (see Geels 2011).

King (2008) argued that enhancing ecological and societal resilience requires more than current alternative systems (such as organic agriculture, permaculture, etc.) can offer. None is the "best," as there is a need for a diversity of agro-ecological systems that together bring about the variation of functions at multiple scales that is required to build true resilience. Gunderson and Pritchard (2002) argued that no single mechanism can guarantee maintenance of resilience; they expressed the opinion that in ecological systems resilience lies in the requisite diversity of functional groups and accumulated ecological capital that provides sources for recovery. This certainly applies to plant breeding. Depending on the ecological and cultural context different choices will be made, and trade-offs will be weighed differently. In plant breeding, agrobiodiversity also implies a diversity in breeding approaches and in seed systems (Louwaars et al. 2011; Louwaars 2018).
In addition, institutional change is required to give space to a multitude of innovations. Typical examples are the variety registration protocols. They are based on the so-called DUS principles: distinctness, uniformity, and stability and on the Value for Cultivating and Use (VCU) testing under conventional growing conditions. These protocols impede innovation in the systems-based breeding orientation and should therefore be reconsidered. Already several European countries have adopted the protocols for testing and registration of cereal cultivars that are adapted to organic or low-input conditions, by including important features, such as weed suppression ability and disease resistance (Osman et al. 2015).

\subsection{Seeds as common good}

Other important aspects of institutional arrangements associated with genetic diversity and food sovereignty are intellectual property rights on plants (IPR). From a systems-based breeding orientation, free access to genetic resources is considered important, as it provides the best conditions for a broad genetic base to enhance food security and food sovereignty. However, the way plant varieties have been developed, released and distributed has changed drastically over time: from publicly freely available resources created by state institutions to highly protected material, produced and managed by the private breeding sector. Since the 1970s, governments have largely withdrawn from public breeding activities and left breeding in the hands of the private sector. Breeding for resistance or tolerance to biotic and abiotic stresses is complex and costly, and hence is currently considered risky. Therefore, the current private business models in breeding require greater financial incentives based on more restrictive IPR to enable these companies to invest in broadening their genetic base (Donnenwirth et al. 2004). A group of non-governmental organizations published a report entitled "Owning seeds, accessing food," in which they expressed their concern that stronger plant variety protection as agreed upon in UPOV 1991 (the 1991 declaration of the International Union for the Protection of New Varieties of Plants (UPOV)) will threaten the right to food for smallholder farmers. They therefore plea for a thorough review of the UPOV rules, and especially for a revision of those aspects of the UPOV rules that impede the informal seed sector and damage the interests of (farmers in) low-income countries (Braunschweig et al. 2014) and highincome countries (Kloppenburg 2010; Luby et al. 2015).

In response to such developments, many new initiatives arose. For example, the Open Source Seed Initiative (OSSI) in the USA explores alternative strategies by promoting and maintaining open access to plant genetic resources worldwide and increases the common pool of plant genetic resources (Kloppenburg 2010; Luby et al. 2015). However, such approaches do not yet solve the issue who is going to pay for the breeding efforts and requires a broadened view. 
Wirz et al. (2017) distinguished three types of goods for seed and plant varieties: cultural, economic, and common good. These authors made a plea to create a balance between these three goods. They also stressed that seed is different from other threatened natural resources, as it gets lost when it is not used. In fact, seed is not only a natural resource, but also a cultural and economic resource. They also call for designing a better balance between public and private breeding activities to allow more diversity in regional-based breeding activities including conservation of traditional crops and varieties.

There are many other examples emerging where partners in the value chain experiment with ways to become co-creators of genetic diversity and share the responsibilities for developing and maintaining new varieties rather than merely acting as donors (see, e.g., Osman et al. 2007; Kotschi and Wirz 2015). This requires new relationships within the value chain including breeders as partners in the food chain or food networks. Fair and green policies should support the exploration of such new breeding organizations or networks. Also, policy support is needed for speeding up the emergence of start-ups which set up new breeding programs to close the gap for small crops and small markets to safeguard diversity in the fields and in our diets.

\subsection{New entrepreneurial models}

Carroll and Shabana (2010) described a possible transition from a narrow view on business strategies focusing on immediate cost savings to enabling a firm to enhance its competitive advantage and create win-win relationships with its community of stakeholders, while at the same time realizing gains from cost and risk reduction and legitimacy and reputation benefits. However, including corporate social responsibility (CSR) not automatically leads to sustainability (Knowles 2014). CSR looks backwards at performance, typically over the last 12 months, while sustainability is forward-looking.

There are examples of companies that want to show top leadership in transitioning towards a more integral sustainability plan (Grayson 2011; Unilever 2017). A Dutch company trading in organic fruits, called Eosta, recently introduced true-cost accounting into its entrepreneurial model (cf. Holden 2013; Eosta et al. 2017). Such integral sustainability thinking should be extended to breeding companies with respect to prioritizing long-term breeding goals.

Wolfe et al. (2008) described various types of breeding programs for organic agriculture ranging from combining conventional and organic markets to fully committed to the organic market. However, producing organic seeds of an existing variety assortment is one thing, but remodeling a breeding program so that it produces varieties suitable for more sustainable farming systems, such as organic agriculture, is another and more radical issue, involving different breeding priorities and selecting under different crop management conditions (Osman et al. 2016; Kokare et al. 2017). Changing breeding priorities also brings up the question to what extent certain cultivar traits are in the interest of a seed company that wants to sell seeds every year. It is a commonly shared secret that potato-breeding companies consider it not in their business interest to select for a high level of virus resistance in potato as a certain level of susceptibility prevents farmers from saving their own seed too often (pers. communication P. Keijzer, 2018). Similarly, persistency of perennial fodder crops like red clover is at the moment not a priority for seed companies (Hoekstra et al. 2018), while persistent cultivars would positively influence soil organic matter build-up, carbon sequestration and soil biodiversity (Van Eekeren et al. 2008). Such dilemmas touch upon the radical change needed in corporate social responsibility when developing a systemsbased breeding orientation.

\subsection{Shared sense of urgency}

In order to trigger fundamental change in the global food systems and in the role of plant breeding in those systems, it is necessary that there is a widely shared sense of urgency for change, also in the objectives of plant breeding. Rockström et al. (2009) indicated that nine planetary boundaries were already overstepped and stressed the urgency to mitigate at least three out of those nine planetary boundaries. These three included biodiversity loss (at species level), climate change, and human interference with the nitrogen cycle. These three overstepped boundaries all have a very close relationship to agriculture. These authors argued that these rates of change cannot continue without significantly eroding the resilience of major components of the earth-system functioning. Especially climate change may hurt agriculture tremendously. The resources to be used to cope with such threats are also becoming increasingly scarce, such as diversity of crops (Khoury and Jarvis 2014) and of the crop wild relatives necessary for breeding (Castañeda-Álvarez et al. 2016).

Urgent innovations can be catalyzed by innovation brokers (Klerkx and Leeuwis 2009). However, the success of innovations also depends on historical and socio-economic contexts (Geels and Schot 2007). Nuijten et al. (2017b) analyzed various cases of introducing in different ways disease resistant cultivars of apple and potato into the market; such introductions were considered urgent in order to enable sustainable organic production of such produce. Nuijten et al. (2017b) formulated key lessons learned from the cases: (i) there must be an urgent need creating a pull strength; (ii) for creating enough pull strength, it is important to involve several stakeholders; (iii) involving all stakeholders requires a shared language and a common culture; this can help to also create push strength; (iv) without adequate push strength, no progress will be realized. 
Systems-based breeding goes a step further and also takes into account long-term societal and ecological benefits that go beyond the direct interest of the value chain. The latter also requires a sense of urgency among the policy makers and the general public, to realize fair and green policies that support appropriate, sustainable innovations.

\subsection{Perspective}

The systems-based plant breeding orientation as defined in this paper will allow plant breeders to not only catch up but also become initiators for more cooperation in making agriculture more ecologically and societally resilient.

Funding information This study was funded by the European Union's Horizon 2020 research and innovation program under grant agreement No 633571, Project Diversifood (Embedding crop diversity and networking for local high quality food system), and No 727230, Project Liveseed (Improve performance of organic agriculture by boosting organic seed and plant breeding efforts across Europe), and by the Iona Stichting. The information provided reflects the views of the authors. The Research Executive Agency is not responsible for any use that may be made of the information provided.

\section{Compliance with ethical standards}

Conflict of interest The authors declare that they have no conflict of interest.

Open Access This article is distributed under the terms of the Creative Commons Attribution 4.0 International License (http:// creativecommons.org/licenses/by/4.0/), which permits unrestricted use, distribution, and reproduction in any medium, provided you give appropriate credit to the original author(s) and the source, provide a link to the Creative Commons license, and indicate if changes were made.

\section{References}

Alkon AH (2013) Food justice, food sovereignty and the challenge of neoliberalism. Food sovereignty: a critical dialogue. Conference Paper \# 38 presented at the 'Food Sovereignty: A Critical Dialogue' international conference, convened by the Yale Program in Agrarian Studies, September 14-15, 2013

Almekinders CJM (2011) The joint development of JM-12.7: a technographic description of the making of a bean variety. NJAS Wageningen Journal of Life Sciences 57:207-216

Almekinders C, Hardon J (eds) (2006) Bringing farmers back into breeding. Experiences with participatory plant breeding and challenges for institutionalisation, Agromisa Special 5, Wageningen, 2006, p. 125. http://documents.plant.wur.nl/cgn/literature/reports/ BringingFarmersBackIntoBreeding 2006.pdf

Bachmann L (2010) Farmer-led participatory plant breeding. Methods and impacts. The MASIPAG farmers Network in the Philippines. In: Goldringer I, Dawson JC, Rey F, Vettoretti A, Chable V, Lammerts van Bueren ET, Finckh M, Barot S (eds) Breeding for resilience: a strategy for organic and low-input farming systems? EUCARPIA 2nd Conference of the Organic and Low-Input Agriculture Section, Paris, France, 1-3 December 2010, p 119-122
Bänziger M, Cooper M (2001) Breeding for low-input conditions and consequences for participatory plant breeding: examples from tropical maize and wheat. Euphytica 122(3):503-519

Barnes AP, Ferreira J, Revoredo-Giha CRG, Hoad S, Hoebe P, Burnett F (2016) The UK Plant Breeding Sector and Innovation (CT-RES042). Report for the Intellectual Property Office. HMSO, London

Barthel S, Crumley C, Svedin U (2013) Bio-cultural refugiasafeguarding diversity of practices for food security and biodiversity. Glob Environ Chang 23:1142-1152. https://doi.org/10.1016/j. gloenvcha.2013.05.001

Bawden R (2010) The community challenge: the learning response. In: Blackmore C (ed) Social learning systems and communities of practice. Springer, London. https://doi.org/10.1007/978-1-84996-1332_3

Bezner Kerr R (2010) Unearthing the cultural and material struggles over seed in Malawi. In: Wittman H, Desmarais AA, Wiebe N (eds) Food sovereignty: reconnecting food, nature and community. Fernwood Publishing, Halifax, pp 134-151

Bradshaw JE (2017) Plant breeding: past, present and future. Euphytica 213(3):1-12. https://doi.org/10.1007/s10681-016-1815-y

Braunschweig T, Meienberg F, Pionetti C, Shashikant S (2014) Owning seeds, accessing food: a human rights impact assessment of UPOV 1991 based on case studies in Kenya, Peru and the Philippines. The Berne Declaration, Zurich, Switzerland. Available at https://www. publiceye.ch/fileadmin/files/documents/saatgut/2014_07_10_ owning_seed_-accessing food_report_def.pdf

Brumlop S, Pfeiffer T, Finckh MR (2017) Evolutionary effects on morphology and agronomic performance of three winter wheat composite cross populations maintained for six years under organic and conventional conditions. Organic Farming 3(1):34-50. https://doi. org/10.12924/of2017.03010034

Brussaard L, Caron P, Campbell B, Lipper L, Sainka S, Rabbinge R, Babin D, Pulleman M (2010) Reconciling biodiversity conservation and food security: scientific challenges for a new agriculture. Curr Opin Environ Sustain 2:34-42. https://doi.org/10.1016/j.cosust. 2010.03.007

Campanelli G, Acciarri N, Campion B, Delvecchio S, Leteo F, Fusari F, Angelini P, Ceccarelli S (2015) Participatory tomato breeding for organic conditions in Italy. Euphytica 204:179-197. https://doi.org/ 10.1007/s10681-015-1362-y

Capra F (1997) The web of life: a new synthesis of mind and matter. Flamingo, London

Cardi T, Stewart CN (2016) Progress of targeted genome modification approaches in higher plants. Plant Cell Rep 35:1401-1416. https:// doi.org/10.1007/s00299-016-1975-1

Carroll AB, Shabana KM (2010) The business case for corporate social responsibility: a review of concepts, research and practice. Int $\mathrm{J}$ Manag Rev 12(1):85-105

Castañeda-Álvarez NP, Khoury CK, Sosa CC, Achicanoy H, Bernau V, Sotelo HS, Vincent H, Eastwood R, Mueller J, Dempewolf H, Guarino L, Ramírez-Villegas J, Jarvis A, Struik PC, Maxted N (2016) Global conservation priorities for crop wild relatives. Nature Plants 2(4):16022. https://doi.org/10.1038/NPLANTS. 2016.22

Ceccarelli S (2014) GMO, organic agriculture and breeding for sustainability. Sustainability 6:4273-4286

Ceccarelli S (2015) Efficiency of plant breeding. Crop Sci 55:87-97

Ceccarelli S, Grando S, Bailey E, Amri A, El-Felah M, Nassif F, Rezgui S, Yahyaoui A (2001) Farmer participation in barley breeding in Syria, Morocco and Tunisia. Euphytica 122(3):521-536

Ceccarelli S, Grando S, Maatougui M, Michael M, Slash M, Haghparast R, Rahmanian M, Taheri A, Al-Yassin A, Benbelkacem A, Labdi M, Mimoun H, Nachit M (2010) Plant breeding and climate change. J Agric Sci 148:627-637

Coomes OT, McGuire SJ, Garine E, Caillon S, McKey D, Demeulenaere E, Jarvis D, Aistara G, Barnaud A, Clouvel P, Emperaire L, Louafi 
S, Martin P, Massol F, Pautasso M, Violon C, Wencélius J (2015) Farmer seed networks make a limited contribution to agriculture? Four common misconceptions. Food Policy 56:41-50

Cooper M, Messina CD, Podlich D, Totir LR, Baumgarten A, Hausmann NJ, Wright D, Graham G (2014) Predicting the future of plant breeding: complementing empirical evaluation with genetic prediction. Crop and Pasture Sci 65(4):311-336. https://doi.org/10.1071/ CP14007

Coote A (2014) Social justice and environmental sustainability can only be achieved together. Open Democracy UK. https://www. opendemocracy.net/ourkingdom/anna-coote/social-justice-andenvironmental-sustainability-can-only-be-achieved-together

Cullis BR, Smith AB, Coomes NE (2006) On the design of early generation variety trials with correlated data. J Agric Biol Environ Stat 11(4):381-393

Cuoco E (2017) Request for prolongation of the temporary experiment set up by Commission implementing decision 2014/150/EU providing for certain derogations for the marketing of populations of plant species pursuant to Council Directive 66/402/EEC. IFOAM EU Group, Brussels. http://www.consilium.europa.eu/en/meetings/env/ 2015/12/st15380 en15 pdf/

Davis J (1989) Breeding for intercrops with special attention to beans for intercropping with maize. Centro Internacional de Agricultura Tropical (CIAT), Butare, RW. p. 9

De Deyn GB, Cornelissen JH, Bardgett RD (2008) Plant functional traits and soil carbon sequestration in contrasting biomes. Ecol Lett 11: 516-531

De Schutter O (2014) Report of the special rapporteur on the right to food. New York: United Nations General Assembly; 24 January 2014, 28 pp. http:/www.srfood.org/images/stories/pdf/officialreports/ 20140310 finalreport en.pdf

Deery DM, Rebetzke GJ, Jimenez-Berni JA, James RA, Condon AG, Bovill WD, Hutchinson P, Scarrow J, Davy R, Furbank RT (2016) Methodology for high-throughput field phenotyping of canopy temperature using airborne thermography. Front Plant Sci 7:1808

Deru JGC, Schilder H, van der Schoot JR, van Eekeren N (2014) Genetic differences in root mass of Lolium perenne varieties under field conditions. Euphytica 199(1-2):223-232. https://doi.org/10.1007/ s10681-014-1129-x

Desclaux D, Nolot JM, Chiffoleau Y, Goze E, Leclerc C (2008) Changes in the concept of genotype 3 environment interactions to fit agriculture diversification and decentralized participatory plant breeding: pluridisciplinary point of view. Euphytica 163:533-546. https://doi. org/10.1007/s10681-008-9717-2

Donnenwirth J, Grace J, Smith S (2004) Intellectual property rights, patents, plant variety protection and contracts: A perspective from the private sector. IP Strategy Today No. 9:19-34. https://ipmall.law. unh.edu/sites/default/files/hosted_resources/PLANT_PATENT_ ARTICLES/tttc-00064-en.pdf

Döring TF, Knapp S, Kovacs G, Murphy K, Wolfe MS (2011) Evolutionary plant breeding in cereals - into a new era. Sustainability 3:1944-1971

Dwivedi SL, Lammerts van Bueren ET, Ceccarelli S, Grando S, Upadhyaya HD, Ortiz R (2017) Diversifying food systems in the pursuit of sustainable food production and healthy diets. Trends Plant Sci 10:842-856

Eosta, Soil \& More, EY, Triodos Bank, Hivos (2017) For food, farming and finance (TCA-FFF). https://www.natureandmore.com/files/ documenten/tca-fff-report.pdf

FAO (2001) The state of food insecurity in the world 2001. Food and Agricultural Organization (FAO), Rome

FAO (2011) Save and grow. A policymaker's guide to the sustainable intensification of smallholder crop production. FAO, Rome, $102 \mathrm{pp}$. http://www.fao.org/ag/save-and-grow/

FAO (2016) The 2030 agenda for sustainable development. http://www. fao.org/sustainable-development-goals/en/
FAO, IFAD, UNICEF, WFP, WHO (2017) The state of food security and nutrition in the world 2017. Building resilience for peace and food security. Rome, FAO. http://www.fao.org/3/a-I7695e.pdf

Fitzgerald D (1993) Farmers deskilled: hybrid corn and farmers' work. Technol Cult 34(2):324-343

Fraser E, Legwegoh A, Krishna KC, CoDyre M, Dias G, Hazen S, Johnson R, Martin R, Ohberg L, Sethuratnam S, Senyd L, Smithers J, Van Acker R, Vansteenkiste J, Wittman H, Yada R (2016) Biotechnology or organic? Extensive or intensive? Global or local? A critical review of potential pathways to resolve the global food crisis. Trends Food Sci Tech 48:78-87. https://doi.org/10.1016/ j.tifs.2015.11.006

Galiè A, Jiggins J, Struik PC, Grando S, Ceccarelli S (2017) Women's empowerment through seed improvement and seed governance: evidence from participatory barley breeding in pre-war Syria. NJAS - Wagen J Life Sci 81:1-8

Galván GA, Kuyper TW, Burger K, Keizer LCP, Hoekstra RF, Kik C, Scholten OE (2011) Genetic analysis of the interaction between Allium species and arbuscular mycorrhizal fungi. Theor Appl Gen 122:947-960

Geels FW (2011) The multi-level perspective on sustainability transitions: responses to seven criticisms. Environ Innov Soc Trans 1: $24-40$

Geels FW, Schot J (2007) Typology of sociotechnical transition pathways. Res Policy 36:399-417

Geißdörfer M, Savaget P, Bocken NMP, Hultink EJ (2017) The circular economy - a new sustainability paradigm? J Clean Prod 143:757768

Gepts P, Hancock J (2006) The future of plant breeding. Crop Sci 46(4): 1630-1634. https://doi.org/10.2135/cropsci2005-12-0497op

Gewin V (2010) Food: an underground revolution. Nature 466:553

Gilbert N (2016) Frugal Farming. Nature 533:308-310

Grayson D (2011) Embedding corporate responsibility and sustainability: Marks \& Spencer. J Manag Dev 30(10):1017-1026

Groenewegen LJM (1977) Multilines as a tool in breeding for reliable yields. Cereal Res Commun 5:12-132

Gunderson LH, Pritchard L (2002) Resilience and the behaviour of largescale systems. Island Press, Washington

Halewood M, Deupmann P, Sthapit BR, Vernooy R, Ceccarelli S (2007) Participatory plant breeding to promote farmers' rights. Bioversity International, Rome, Italy, $7 \mathrm{pp}$. https://www. bioversityinternational.org/e-library/publications/detail/ participatory-plant-breeding-to-promote-farmers-rights/

Harrison PA, Berry PM, Simpson G, Haslett JR, Blicharska M, Bucur M, Dunford R, Egoh B, Garcia-Llorente M, Geamănă N, Geertsema W, Lommelen E, Meiresonne L, Turkelboom F (2014) Linkages between biodiversity attributes and ecosystem services: a systematic review. Ecosyst Serv 9:191-203. https://doi.org/10.1016/j.ecoser. 2014.05.006

Haverkort AJ, Boonekamp PM, Hutten R, Jacobsen E, Lotz LAP, Kessel GJT, Vossen JH, Visser RGF (2016) Durable late blight resistance in potato through dynamic varieties obtained by cisgenesis: scientific and societal advances in the DuRPh project. Potato Res 59(1):35-66

Henry A, Carlos Rosas J, Beaver JC, Lynch JP (2010) Multiple stress response and belowground competition in multilines of common bean (Phaseolus vulgaris L.). Field Crops Res 117:209-218

Hisschemöller M, Hoppe R (1995) Coping with intractable controversies: the case for problem structuring in policy design and analysis. Knowl Policy 8:40-60

Hoekstra NJ, De Deyn GB, Xu Y, Prinsen R, Van Eekeren N (2018) Red clover varieties of Mattenklee type have higher production, protein yield and persistence than Ackerklee types in grass-clover mixtures. Grass Forage Sci 73:297-308. https://doi.org/10.1111/gfs.12307

Hoffmann I, From T, Boerma D (2014) Ecosystem services provided by livestock species and breeds, with special consideration to the 
contributions of small-scale livestock keepers and pastoralists. FAO, Rome http://www.fao.org/3/a-at598e.pdf

Holden P (2013) The true cost of food. Sustainable Food Trust, Bristol (UK). http://sustainablefoodtrust.org/key-issues/true-costaccounting/true-cost-posts/ (visited 19 November 2017)

Howard PH (2009) Visualizing consolidation in the global seed industry: 1996-2008. Sustainability 1(4):1266-1287. https://doi.org/10.3390/ su1041266

Howard PH (2015) Intellectual property and consolidation in the seed industry. Crop Sci 55(6):2489-2495

Huang J, Tichit M, Poulot M, Darly S, Li S, Petit C, Aubry C (2015) Comparative review of multifunctionality and ecosystem services in sustainable agriculture. J Environ Manag 149:138-147

Jacobsen S-E, Sørensen M, Pedersen SM, Weiner J (2013) Feeding the world: genetically modified crops versus agricultural biodiversity. Agron Sustain Dev 33(4):651-662

Kadam N, Tamilselvan A, Lawas L, Quinones C, Bahugna R, Thomson M, Dingkuhn M, Muthurajan R, Struik PC, Yin X, Krishna Jagadish SV (2017) Genetic control of plasticity in root morphology and anatomy of rice in response to water-deficit. Plant Physiol 174: $2302-2315$

Khoury CK, Jarvis A (2014) The changing composition of the global diet: Implications for CGIAR research. CIAT Policy Brief No. 18. Centro Internacional de Agricultura Tropical, p. 6

Khoury CK, Bjorkman AD, Dempewolf H, Ramirez-Villegas J, Guarino L, Jarvis A, Rieseberg LH, Struik PC (2014) Increasing homogeneity in global food supplies and the implications for food security. Proc Natl Acad Sci U S A 111:4001-4006. https://doi.org/10.1073/ pnas. 1313490111

Khush GS (2001) Green revolution: the way forward. Nat Rev Genet 2: $815-822$

Kiers ET, Leakey RRB, Izac A-M, Heinemann JA, Rosenthal E, Nathan D, Jiggins J (2008) Agriculture at a crossroads. Science 320(5874): 320-321

King CA (2008) Community resilience and contemporary agri-ecological systems: reconnecting people and food, and people with people. Syst Res Behav Sci 25:111-124

King CA, Powell N (2000) Informing participatory action research (PAR) with the principles of ecological systems. Proceedings of the 5th Action Learning, Action Research and Process Management and 9th on Participatory Action Research, Ballarat, Australia, 10-13 September, 2000. ALARPM, Queensland Australia

Klerkx L, Leeuwis C (2009) Establishment and embedding of innovation brokers at different innovation system levels: insights from the Dutch agricultural sector. Technol Forecast Soc Chang 76:849-860

Kloppenburg J (2010) Impeding dispossession, enabling repossession: biological open source and the recovery of seed sovereignty. J Agrar Chang 10(3):367-388

Knowles (2014) What's the difference between CSR and sustainability? https://www.2degreesnetwork.com/groups/2degrees-community/ resources/whats-difference-between-csr-and-sustainability/

Kokare A, Legzdina L, Maliepaard C, Niks RE, Lammerts van Bueren ET (2017) Comparison of selection efficiency for spring barley (Hordeum vulgare L.) under organic and conventional farming conditions. Crop Sci 57(2):626-636. https://doi.org/10.2135/ cropsci2015.11.0691

Koohafkan P, Altieri MA, Holt Gimenez E (2012) Green agriculture: foundations for biodiverse, resilient and productive agricultural systems. Int J Agric Sustain 10(1):61-75. https://doi.org/10.1080/ 14735903.2011.610206

Koornneef M, Stam P (2001) Changing paradigms in plant breeding. Plant Physiol 125:156-159. https://doi.org/10.1104/pp.125.1.156

Kotschi J, Wirz J (2015) Who pays for seeds? Thoughts on financing organic plant breeding. Working Paper. AGRECOL and Section for Agriculture. Marburg and Dornach. Available at: http://www. agrecol.de/files/Kotschi_\&_Wirz\%20Engl_12_05_15.pdf
Kuyper TW, Struik PC (2014) Epilogue: global food security, rhetoric, and the sustainable intensification debate. Curr Opin Environ Sustain 8:71-79. https://doi.org/10.1016/j.cosust.2014.09.004

Lammerts van Bueren ET, Struik PC (2017) Diverse concepts for breeding for nitrogen use efficiency. A review. Agron Sustain Dev 37(5): 50. https://doi.org/10.1007/s13593-017-0457-3

Lammerts van Bueren ET, Østergård H, De Vriend H, Backes G (2010) Role of molecular markers and marker assisted selection in breeding for organic and low-input agriculture. Euphytica 175:51-64

Lammerts van Bueren ET, Engelen C, Hutten R (2014) Participatory potato breeding model involving organic farmers and commercial breeding companies in the Netherlands. In: Hubbard K (ed) Organic seed growers conference Proceedings, January 30-February 1, 2014, Corvallis, OR. Organic Seed Alliance, Port Townsend, WA, p 69-73

Lauer JG, Bijl CG, Grusak MA, Baenziger PS, Boote K, Lingle S, Carter T, Kaeppler S, Boerma R, Eizenga G, Carter P, Goodman M, Nafziger E, Kidwell K, Mitchell R, Edgerton MD, Quesenberry K, Willcox MC (2012) The scientific grand challenges of the 21st century for the Crop Science Society of America. Crop Sci 52:10031010. https://doi.org/10.2135/cropsci2011.12.0668

Li J, Lammerts van Bueren ET, Huang K, Qin L, Song Y (2013) The potential of participatory hybrid breeding. Int J Agric Sust 11(3): 234-251. https://doi.org/10.1080/14735903.2012.728050

Li J, Lammerts van Bueren ET, Leeuwis C, Jiggins J (2014) Expressing the public value of plant genetic resources by organising novel relationships: the contribution of selected participatory plant breeding and market-based arrangements. J Rural Stud 36:182-196

Lindner B (2004) Economic issues for plant breeding - public funding and private ownership. Australasian Agribusiness Review 12. www. agrifood.info/review/2004/Lindner.html

Louwaars N (2018) Plant breeding and diversity: a troubled relationship? Euphytica 214:114. https://doi.org/10.1007/s10681-018-2192-5

Louwaars N, Le Coent P, Osborn T (2011) Seed systems and plant genetic resources for food and agriculture. AO, Rome

Luby CH, Kloppenburg J, Michaels TE, Goldman IL (2015) Enhancing freedom to operate for plant breeders and farmers through open source plant breeding. Crop Sci 55:2481-2488

Lucht JM (2015) Public acceptance of plant biotechnology and GM crops. Viruses 7:4254-4281. https://doi.org/10.3390/v7082819

Lynch JP (2011) Root phenes for enhanced soil exploration and phosphorus acquisition: tools for future crops. Plant Physiol 156:1041-1049. https://doi.org/10.1104/pp.111.175414

Madsen KH, Sandøe P (2005) Ethical reflections on herbicide-resistant crops. Pest Manag Sci 61(3):318-325

Mahfouz MM, Cardi T, Stewart CN (2016) Next-generation precision genome engineering and plant biotechnology. Plant Cell Rep 35: 1397-1399. https://doi.org/10.1007/s00299-016-2009-8

Montenegro de Wit M (2016) Stealing into the wild: conservation science, plant breeding and the makings of new seed enclosures. $\mathrm{J}$ Peasant Stud 1-44. https://doi.org/10.1080/03066150.2016. 1168405

Mostovicz EI, Kakabadse A, Kakabadse NK (2011) The four pillars of corporate responsibility: ethics, leadership, personal responsibility and trust. Corp Gov 11(4):489-500. https://doi.org/10.1108/ 14720701111159307

Mundt CC (2002) Use of multiline cultivars and cultivar mixtures for disease management. Annu Rev Phytopathol 40:381-410. https:// doi.org/10.1146/annurev.phyto.40.011402.113723

Munns R, Richards RA (2007) Recent advances in breeding wheat for drought and salt stresses. In: Jenks MA, Hasegawa PM, Jain SM (eds) Advances in molecular breeding towards drought and salt tolerant crops. Springer, Dordrecht, pp 565-585. https://doi.org/10. 1007/978-1-4020-5578-2_22

Murphy K, Lammer D, Lyon S, Carter B, Jones S (2005) Breeding for organic and low-input farming systems: an evolutionary- 
participatory breeding method for inbred cereal grains. Renew Agric Food Syst 20:48-55. https://doi.org/10.1079/RAF20048

Murphy KM, Carter AH, Jones SS (2014) Evolutionary breeding and climate change. In: Kole C (ed) Genomics and breeding for climate-resilient crops. Springer, Berlin, pp 377-389

Murphy KM, Bazile D, Kellogg J, Rahmanian M (2016) Development of a worldwide consortium on evolutionary participatory breeding in quinoa. Front Plant Sci 7:608. https://doi.org/10.3389/fpls.2016. 00608

Nicotra AB, Atkin OK, Bonser SP, Davidson AM, Finnegan J, Mathesius U, Poot P, Purugganan MD, Valladares F, Van Kleunen M (2010) Plant phenotypic plasticity in a changing climate. Trends Plant Sci 15(12):684-692. https://doi.org/10.1016/j.tplants.2010.09.008

Nuijten E, Temudo M, Richards P, Okry F, Teeken B, Mokuwa A, Struik PC (2013) Towards a new approach for understanding interactions of technology with environment and society in small-scale rice farming. In: Wopereis MCS, Johnson DE, Ahmadi N, Tollens E, Jalloh A (eds) Realizing Africa's Rice promise. CABI Publishing, Wallingford, pp 355-366

Nuijten E, Messmer MM, Lammerts van Bueren ET (2017a) Concepts and strategies of organic plant breeding in light of novel breeding techniques. Sustainability 9(1):18. https://doi.org/10.3390/ su9010018

Nuijten E, de Wit J, Janmaat L, Schmitt A, Tamm L, Lammerts van Bueren ET (2017b) Understanding obstacles and opportunities for successful market introduction of crop varieties with resistance against major diseases. Org Agric (first online). doi:https://doi.org/ 10.1007/s13165-017-0192-8

Osman AM, Müller K-J, Wilbois K-P (eds) (2007) Different models to finance plant breeding. Proceedings of the ECO-PB International Workshop on 27 February 2007 in Frankfurt, Germany. European Consortium for Organic Plant Breeding, Driebergen/Frankfurt. 33 pp. available at: http://www.eco-pb.org/fileadmin/eco-pb/ documents/reports proceedings/proceedings 070227.pdf

Osman AM, Bonthuis H, Van den Brink L, Struik PC, Almekinders CJM, Lammerts van Bueren ET (2015) The case of spring wheat value for cultivation and use testing in the Netherlands. Org Agric 5:101-111. https://doi.org/10.1007/s13165-014-0085-z

Osman AM, Almekinders CJM, Struik PC, Lammerts van Bueren ET (2016) Adapting spring wheat breeding to the needs of the organic sector. NJAS - Wageningen Journal of Life Sciences 76:55-63

Ostrom E (2008) The challenge of common-pool resources. Environment: Science and Policy for Sustainable Development 50: $8-21$

Peleman JD, Rouppe van der Voort J (2003) Breeding by design. Trends Plant Sci 8(7):330-334

Perez JE, Carrion VJ, Bosse M, Ferrão LFV, De Hollander M, Garcia AAF et al (2017) Linking rhizosphere microbiome composition of wild and domesticated Phaseolus vulgaris to genotypic and root phenotypic traits. ISME J 11:2244-2257. https://doi.org/10.1038/ ismej.2017.85

Power AG (2010) Ecosystem services and agriculture: tradeoffs and synergies. Phil Trans R Soc B 365:2959-2971

Raggi L, Ciancaleoni S, Torricelli R, Terzi V, Ceccarelli S (2017) Evolutionary breeding for sustainable agriculture: selection and multi-environmental evaluation of barley populations and lines. Field Crops Res 204:76-88

Rockström J, Steffen W, Noone K, Persson Å, Chapin FS, Lambin EF et al (2009) A safe operating space for humanity. Nature 461:472-475. https://doi.org/10.1038/461472a

Rosset PM, Sosa BM, Jaime AM, Lozano DR (2011) The Campesino-toCampesino agroecology movement of ANAP in Cuba: social process methodology in the construction of sustainable peasant agriculture and food sovereignty. J Peasant Stud 38(1):161-191

Senge PM (2006) The fifth discipline: the art and discipline of the learning organization. Broadway Business, New York
Shelton AC, Tracy WF (2015) Recurrent selection and participatory plant breeding for improvement of two organic open-pollinated sweet corn (Zea mays L.) populations. Sustainability 7:5139-5152. https://doi.org/10.3390/su705513

Shi W, Yin X, Struik PC, Solis C, Xie F, Schmidt RF, Huang M, Zou Y, Ye C, Jagadish SVK (2017) High day- and night-time temperatures affect grain growth dynamics in contrasting rice genotypes. J Exp Bot 68(18):5233-5245. https://doi.org/10.1093/jxb/erx344

Snapp SS, Blackie MJ, Gilbert RA, Bezner Kerr R, Kanyama-Phiri GY (2010) Biodiversity can support a greener revolution in Africa. Proc Natl Acad Sci U S A 107:20840-20845. https://doi.org/10.1073/ pnas.1007199107

Sperling L, Loevinsohn ME, Ntabomvura B (1993) Rethinking the farmers role in plant breeding: local bean experts and on-station selection in Rwanda. Exp Agric 29(4):509-519

Sperling L, Ashby JA, Smith ME, Weltzien E, McGuire S (2001) A framework for analysing participatory plant breeding approaches and results. Euphytica 122:439-450

Struik PC, Kuyper TW (2014) Editorial overview: sustainable intensification to feed the world: concepts, technologies and trade-offs. Curr Opin Environ Sust 8:vi-viii. https://doi.org/10.1016/j.cosust.2014. 10.008

Struik PC, Kuyper TW (2017) Sustainable intensification in agriculture: the richer shade of green. A review. Agron Sustain Dev 37:39

Struik PC, Kuyper TW, Brussaard L, Leeuwis C (2014) Deconstructing and unpacking scientific controversies in intensification and sustainability: why the tensions in concepts and values? Curr Opin Environ Sust 8:80-88. https://doi.org/10.1016/j.cosust.2014.10.002

Sumberg J, Thompson J, Woodhouse P (2013) Why agronomy in the developing world has become contentious. Agric Hum Values 30(1):71-83

Suso MJ, Bebeli PJ, Christmann S, Mateus C, Negri V, Pinheiro de Carvalho MAA, Torricelli R, Veloso MM (2016) Enhancing legume ecosystem services through an understanding of plant-pollinator interplay. Front Plant Sci 7:333. https://doi.org/10.3389/fpls.2016. 00333

Teshome A, Baum BR, Fahrig L, Torrance JK, Lambert JD (1997) Sorghum landrace variation and classification in north Shewa and south Welo, Ethiopia. Euphytica 97:255-263

Tilman D, Cassman KG, Matson PA, Naylor R, Polasky S (2002) Agricultural sustainability and intensive production practices. Nature 418:671-677. https://doi.org/10.1038/nature01014

Tomlinson I (2013) Doubling food production to feed the 9 billion: a critical perspective on a key discourse of food security in the UK. J Rural Stud 29:81-90

Unilever (2017) Sustainable living. https://www.unilever.com/ sustainable-living/

United Nations (2015) Transforming our world: the 2030 Agenda for Sustainable Development. Resolution adopted by the General Assembly on 25 September 2015. United Nations A/RES/70/1. Available at: https://sustainabledevelopment.un.org/content/ documents $/ 21252030 \% 20$ Agenda $\% 20$ for $\% 20$ Sustainable $\%$ 20Development\%20web.pdf (last visited 18 November 2017)

Van der Weijden WJ, Huber MAS, Jetten TH, Blom P, Van Egmond ND, Lauwers L, Van Ommen B, Van Vilsteren A, Wijffels HHF, Van der Zijpp AJ, Lammerts van Bueren ET (2012) Towards an integral approach to sustainable agriculture and healthy nutrition. Council for Integral Sustainable Agriculture and Nutrition (RIDL\&V), Zeist, The Netherlands, pp. 42 http://www.ridlv.nl/

Van Eekeren N, Bommelé L, Bloem J, Schouten T, Rutgers M, de Goede R, Reheul D, Brussaard L (2008) Soil biological quality after 36 years of ley-arable cropping, permanent grassland and permanent arable cropping. Appl Soil Ecol 40:432-446

Waltz E (2009) GM crops: battlefield. Nature 461:27-32. https://doi.org/ $10.1038 / 461027 \mathrm{a}$ 
Wirz J, Kunz P, Hurter U (2017) Seed as a Commons. Breeding as a source for real economy, law and culture. Goetheanum and Fund for Crop Development, Switzerland

Wittman H (2011) Food sovereignty: a new rights framework for food and nature? Environ Soc Adv Res 2:87-105. https://doi.org/10. 3167/ares.2011.020106

Wolfe MS, Baresel JP, Desclaux D, Goldringer I, Hoad S, Kovacs G, Löschenberger F, Miedaner T, Østergård H, Lammerts van Bueren ET (2008) Developments in breeding cereals for organic agriculture. Euphytica 163:323-346
Yin X, Struik PC (eds) (2016) Crop systems biology - narrowing the gaps between crop modelling and genetics. Springer, Zurich, p 233

Yin X, Struik PC, Kropff MJ (2004) Role of crop physiology in predicting gene-to-phenotype relationships. Trends Plant Sci 9(9): 426-432. https://doi.org/10.1016/j.tplants.2004.07.007

Zimmerer KS (1998) The ecogeography of Andean potatoes. Versatility in farm regions and fields can aid sustainable development. Bioscience 48(6):445-454 